\title{
Numerical simulations of windblown dust over complex terrain: the Fiambalá Basin episode in June 2015
}

\author{
Leonardo A. Mingari ${ }^{1,6,7}$, Estela A. Collini ${ }^{2,6}$, Arnau Folch ${ }^{3}$, Walter Báez ${ }^{4}$, Emilce Bustos ${ }^{4}$, María Soledad Osores ${ }^{1,5,6}$, \\ Florencia Reckziegel $^{4}$, Peter Alexander ${ }^{1,7}$, and José G. Viramonte ${ }^{4}$ \\ ${ }^{1}$ Consejo Nacional de Investigaciones Científicas y Técnicas (CONICET), Buenos Aires, Argentina \\ ${ }^{2}$ Servicio de Hidrografía Naval (SHN), Buenos Aires, Argentina \\ ${ }^{3}$ Barcelona Supercomputing Center (BSC), Barcelona, Spain \\ ${ }^{4}$ INENCO-GEONORTE (UNSa-CONICET), Salta, Argentina \\ ${ }^{5}$ Comisión Nacional de Actividades Espaciales (CONAE), Buenos Aires, Argentina \\ ${ }^{6}$ Servicio Meteorológico Nacional (SMN), Buenos Aires, Argentina \\ ${ }^{7}$ Instituto de Física de Buenos Aires (IFIBA), Buenos Aires, Argentina \\ Correspondence to: Leonardo A. Mingari (lmingari@gmail.com)
}

Received: 24 September 2016 - Discussion started: 19 December 2016

Revised: 22 April 2017 - Accepted: 26 April 2017 - Published: 9 June 2017

\begin{abstract}
On 13 June 2015, the London Volcanic Ash Advisory Centre (VAAC) warned the Buenos Aires VAAC about a possible volcanic eruption from the Nevados Ojos del Salado volcano $(6879 \mathrm{~m})$, located in the Andes mountain range on the border between Chile and Argentina. A volcanic ash cloud was detected by the SEVIRI instrument on board the Meteosat Second Generation (MSG) satellites from 14:00 UTC on 13 June.
\end{abstract}

In this paper, we provide the first comprehensive description of this event through observations and numerical simulations. Our results support the hypothesis that the phenomenon was caused by wind remobilization of ancient pyroclastic deposits (ca. $4.5 \mathrm{ka}$ Cerro Blanco eruption) from the Bolsón de Fiambalá (Fiambalá Basin) in northwestern Argentina. We have investigated the spatiotemporal distribution of aerosols and the emission process over complex terrain to gain insight into the key role played by the orography and the condition that triggered the long-range transport episode.

Numerical simulations of windblown dust were performed using the ARW (Advanced Research WRF) core of the WRF (Weather Research and Forecasting) model (WRF-ARW) and FALL3D modeling system with meteorological fields downscaled to a spatial resolution of $2 \mathrm{~km}$ in order to resolve the complex orography of the area. Results indicate that favorable conditions to generate dust uplifting occurred in northern Fiambalá Basin, where orographic effects caused strong surface winds. According to short-range numerical simulations, dust particles were confined to near-ground layers around the emission areas. In contrast, dust aerosols were injected up to 5-6 km high in central and southern regions of the Fiambalá Basin, where intense ascending airflows are driven by horizontal convergence.

Long-range transport numerical simulations were also performed to model the dust cloud spreading over northern Argentina. Results of simulated vertical particle column mass were compared with the MSG-SEVIRI retrieval product. We tested two numerical schemes: with the default configuration of the FALL3D model, we found difficulties to simulate transport through orographic barriers, whereas an alternative configuration, using a numerical scheme to more accurately compute the horizontal advection in abrupt terrains, substantially improved the model performance.

\section{Introduction}

On 13 June 2015, the London Volcanic Ash Advisory Centre (VAAC) warned the Buenos Aires VAAC about a possible volcanic eruption from the Nevados Ojos del Salado volcano, the highest volcano in the world $(6879 \mathrm{~m})$, located in the Andes mountain range on the border between Chile and Argentina. A volcanic ash cloud was detected by the infrared 
channels of the Spinning Enhanced Visible and Infrared Imager (SEVIRI) instrument on board the MSG satellites from 14:00 UTC (11:00 LT) on 13 June. In collaboration with a research group specialized in central Andes volcanoes, Collini et al. (2015) concluded that the phenomenon was caused by remobilization of ancient pyroclastic deposits from the Bolsón de Fiambalá (Fiambalá Basin).

The Fiambalá Basin is an intermontane depression with a basin floor elevation of around $1650 \mathrm{~m}$ situated along the eastern flanks of the Andes mountain range in northwestern Argentina (Carrapa et al., 2006; McPherson, 2008) at approximately $27^{\circ} 45^{\prime} \mathrm{S}, 67^{\circ} 45^{\prime} \mathrm{W}$. The dunes of Fiambalá Basin are mainly a product of the aeolian reworked pyroclastic materials originating from the Cerro Blanco strong volcanic eruption, one of the greatest eruptions of the central Andes during the Holocene, which occurred ca. 4500 years ago (Báez et al., 2015; Fernandez Turiel et al., 2015). Wind activity has continued to mobilize this pyroclastic material until today, turning the Fiambalá Basin into a major dust source in northwestern Argentina.

Several theoretical and experimental studies focus on Saharan and Asian dust (Marticorena et al., 1997; Middleton and Goudie, 2001; Shao and Dong, 2006). However, there are fewer studies regarding dust activity in South America (e.g., Middleton, 1986; Kurgansky et al., 2011; Gaiero, 2007). Specifically, areas with persistent dust activity in central and northwestern Argentina have been identified as major dust sources of South America (Prospero et al., 2002). The forecast of dust episodes in these regions is hindered by the scarcity of meteorological stations and the presence of an extremely complex topography. As a consequence, a significant uncertainty exists in the identification of dust sources, emission rates, transport mechanisms, and particle characteristics.

Recently, recurrent events of volcanic ash mobilized by wind in Patagonia caused multiple impacts on the environment for several months, such as severe deterioration of air quality and airport disruptions (Wilson et al., 2013), as a consequence of the volcanic eruptions of the Cordón Caulle volcanic complex in 2011 (Collini et al., 2013) and the Calbuco volcano in 2015 (Romero et al., 2016; Reckziegel et al., 2016). These eruptions blanketed a vast area of Patagonia in Argentina with volcanic ash. An outstanding summary of the 2011 Cordón Caulle eruption by Elissondo et al. (2016) describes in detail the areas and activities that suffered the impact of the volcanic ash plume and deposition from the eruption as well as events of volcanic ash resuspension. The authors mention several types of impacts, including road closure, cuts of electric and water supply, discontinuation of activities in urban areas, health problems, agricultural and livestock disruptions, vegetation damage, and animal death. In distal areas $(1 \mathrm{~cm}$ or less of tephra deposit), the impact included agricultural and livestock disruptions, interruption of transport systems (closure of airports and roads), and discontinuation of activities during days of tephra fall or resuspen- sion. Additionally, remarkable events of volcanic ash resuspension occur in other areas of the world, including Alaska (Hadley et al., 2004) and Iceland (Leadbetter et al., 2012; Liu et al., 2014). In fact, the London VAAC provides daily resuspended ash forecasts to the Icelandic Met Office.

At present, several global and regional dust forecast systems are available (Tegen and Fung, 1994; Nickovic et al., 2001; Benedetti et al., 2014). However, studies focused on the performance of dispersion models simulating concentrations of windblown dust in South America are scarce (e.g., Johnson et al., 2010; Gaiero et al., 2013). For example, events of volcanic ash resuspension in Patagonia were recently simulated using the WRF-ARW/FALL3D modeling system with promising results (Folch et al., 2014; Reckziegel et al., 2016). Dust models simulate the main processes of the dust cycle: emission, transport, and deposition (Tegen, 2003). Customarily, parametrization of dust emission depends on both soil conditions and surface wind stress (Shao, 2001; Kok et al., 2012). Soils with readily erodible sediments of fine particles and low soil moisture content are most sensitive to dust emission (Marticorena and Bergametti, 1995). Descriptions of the dust emission processes involve phenomena related to a wide range of scales, such as microscale (e.g., boundary layer mixing) or mesoscale (e.g., flow over mountain terrain), which may not be resolved by dust models (Tegen and Schulz, 2014).

Orography alters the surface flow and consequently the emission and transport of dust in many ways (Knippertz and Stuut, 2014). For example, wind tunnel measurements demonstrated the influence of complex terrain on dust mobilization (Xuan and Robins, 1994). Recently, a strong dust event in the complex terrain of the Dead Sea valley was simulated with the model system COSMO-ART (Vogel et al., 2009) using a horizontal grid spacing of $\sim 3 \mathrm{~km}$, producing a reasonable spatiotemporal distribution of near-surface dust concentration, consistent with available measurements (Kishcha et al., 2016). In addition, Liu and Westphal (2001) showed that a better resolved topography leads to improved dust simulations over Asia. In this context, the performance of dust models in complex terrains is challenging because (i) local topography plays a key role in the description of the temporal and spatial distribution of aerosol particles, as low-level wind is closely related to geographic features and the nature of the underlying surface, and (ii) almost all major dust sources are in semi-arid and arid low-lying regions or in lands adjacent to strong topographical highs (Prospero et al., 2002).

In this paper, numerical simulations of windblown dust were performed using the FALL3D volcanic ash dispersal model (Costa et al., 2006; Folch et al., 2009) driven by the WRF-ARW meteorological model (Skamarock et al., 2008). We assessed the ability of this modeling strategy to properly represent the emission and transport of dust in the complex terrain environment of the Andes range using the episode of 13 June 2015 as a test case. The meteorological fields were 
downscaled to a spatial resolution of $2 \mathrm{~km}$ to resolve the orographic features of the Fiambalá Basin. Subsequently, shortand large-range simulations were performed and the results compared with the MSG-SEVIRI retrieval product.

This work is framed in the context of efforts for the development of operational forecasting capabilities to predict the occurrence of volcanic ash mobilization in the Andean volcanic region. The final product is intended to provide support to VAACs and air quality agencies.

This work is organized as follows: Sect. 2 provides a description of the region in terms of the geological setting with a review of the current understanding of the local dust activity. Section 3 details the modeling strategy applied to the episode of 13 June 2015 and summarizes the parametrizations of the emission scheme. An overview of the dust outbreak with the associated meteorological conditions is included in Sect. 4. In Sect. 5, we present the results of numerical simulations, addressing the impact of the complex orography on the simulations. The findings are discussed and conceptually integrated in Sect. 6.

\section{Background}

\subsection{Geological setting}

The Andes is a north-south orogen located along the western margin of South America and is related to the subduction of the Farallón-Nazca and Antarctica plates beneath the South American Plate. The main topographic feature in central Andes is the high-elevation Altiplano-Puna plateau. The southern edge of the Altiplano-Puna plateau coincides with the ENE-trending Ojos del Salado-San Buenaventura (OSSB) volcanic lineament (Álvarez et al., 2015, and references therein). This lineament, transversal to the Andean strike, starts at the Chilean Central Valley and extends for almost $300 \mathrm{~km}$ into the back-arc region. The OSSB volcanic lineament is a prominent mountain range formed by stratovolcanoes including some of the highest volcanoes in the world (e.g., Ojos del Salado, Tres Cruces, and Incahuasi volcanoes) as well as by dome complexes and collapse calderas (Baker et al., 1987; Mpodozis et al., 1996; Seggiaro et al., 2000; Montero Lopez et al., 2010a, b, c; Báez et al., 2015; Bustos et al., 2015). Since Neogene times, shallowing of the subducting slab and lithospheric delamination explains the eastward broadening of the arc magmatism along ENE normal and right lateral neotectonic structures to form the OSSB lineament (Kay and Coira, 2009). The OSSB volcanic lineament includes some volcanic centers considered active (last eruption $<10 \mathrm{ka}$ ) but there are no reports of confirmed historical eruptions in the region.

The Cerro Blanco Volcanic Complex (CBVC) is located on the eastern edge of the OSSB volcanic lineament (Fig. 1) and is defined as a nested calderas system with associated domes and pyroclastic deposits (Seggiaro et al., 2000; Vira-

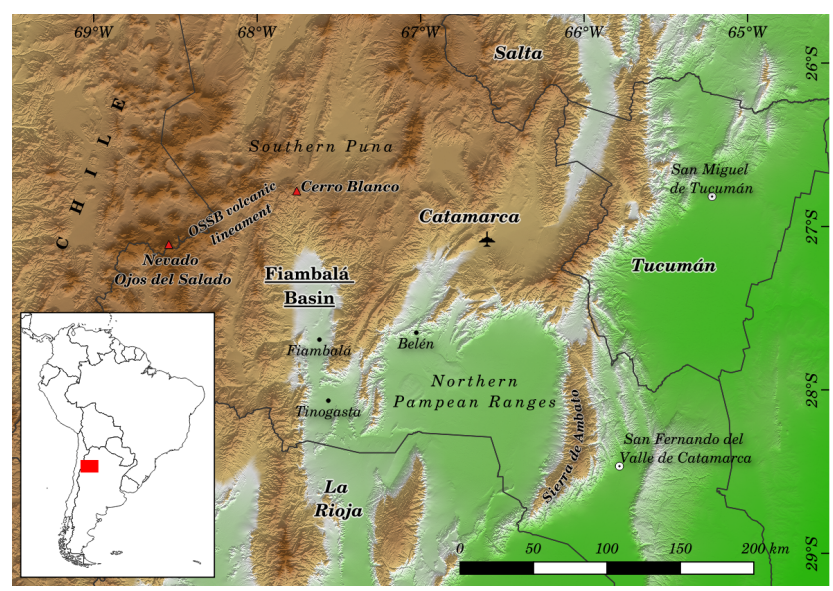

Figure 1. Map of NW Argentina showing the complex terrain environment of the region under study. The Fiambalá Basin is an intermontane depression located in the proximity of the Ojos del Salado-San Buenaventura (OSSB) volcanic lineament, in a transitional region between the southern Puna plateau and the northern Pampean ranges. The triangles indicate the location of volcanoes mentioned in the text. The location of an automatic weather station at Catamarca Airport is shown south of San Fernando del Valle de Catamarca.

monte et al., 2004, 2005; Arnosio et al., 2005). All erupted products are rhyolitic/rhyodacitic in composition and Middle Pleistocene-Holocene in age (Viramonte et al., 2008; Arnosio et al., 2008; Montero Lopez et al., 2010a). The CBVC had at least two large-scale eruptions (volcanic explosivity index $\geq 6$ ) over the past 100000 years (Báez et al., 2015). Particularly the caldera forming Cerro Blanco eruption (4200 BP) constitutes one of the greater Holocene volcanic events in central Andes (Fernandez Turiel et al., 2015; Báez et al., 2015). During the paroxysmal phase of the Cerro Blanco eruption pyroclastic density currents that spread radially as far as $35 \mathrm{~km}$ from the vent were generated $\left(15 \mathrm{~km}^{3}\right.$ minimum bulk volume of ignimbrites) (Báez et al., 2015). Also significant ash fall deposits were produced $\left(110 \mathrm{~km}^{3}\right.$ bulk volume) and covered much of northwestern Argentina (Fernandez Turiel et al., 2015).

The Bolsón de Fiambalá (Fiambalá Basin) is an intermontane depression located $40 \mathrm{~km}$ southward of Cerro Blanco caldera, in a transitional region between the southern Puna and the northern Pampean ranges. The Fiambalá Basin floor is $2000 \mathrm{~m}$ below the average elevation of the southern Puna. During the Cerro Blanco eruption, the Fiambala Basin received a large volume of pyroclastic fallout deposits and a lesser extent of ignimbrite deposits. The unconsolidated nature of the deposits related to the Cerro Blanco eruption (Báez et al., 2015) allowed the rapid remobilization of pyroclastic material deposited in nearby areas to the Fiambalá Basin. Wind activity continued to mobilize this pyroclastic material until today turning the Fiambalá Basin into one of the major dust sources in northwestern Argentina. 


\subsection{Dust activity in the region}

Major dust sources in South America are located along a north-south-oriented band of arid and semi-arid land from the Argentine Patagonia to the coast of Peru (Gaiero et al., 2013). Three areas have been identified as persistent dust sources in South America (Prospero et al., 2002): (i) Patagonia $\left(\sim 50-39^{\circ} \mathrm{S}\right)$, (ii) central-western Argentina $\left(36-26^{\circ} \mathrm{S}\right)$, and (iii) the Puna-Altiplano Plateau $\left(\sim 26-15^{\circ} \mathrm{S}\right)$. According to model-predicted annual emission rates in South America (Johnson et al., 2010), Patagonia is expected to contribute over $95 \%$ of mineral dust emissions, with the remaining emissions attributed to regions in western Argentina.

The dust activity in Argentina shows seasonal and diurnal patterns. For example, Middleton (1986) mentions that the dust activity season occurs from June to October at $20-25^{\circ} \mathrm{S}$ (northern Argentina) and from October to February at 40$45^{\circ} \mathrm{S}$ (southern Argentina). Typically, a diurnal maximum is observed in the afternoon hours.

In the Puna Andean plateau $\left(28-22^{\circ} \mathrm{S}\right.$, northwestern Argentina), dry salt basins and lake beds are important dust sources (Middleton, 1986). The dust activity intensifies during the austral winter in this region due to the strong winds resulting from the presence of the subtropical jet stream. In winter, when there is a large temperature gradient between the tropics and the southern polar region, the jet stream becomes stronger, reaching its northernmost position with its core at $30^{\circ} \mathrm{S}$ (Garreaud, 2009). Winds prevailing in the middle and upper troposphere favor a dry winter climate over the Puna because the Andes block the westerly flow from the Pacific Ocean (Gaiero et al., 2013). As a result, significant dust storms are observed in the region.

\section{Modeling strategy}

Our modeling strategy aims to properly represent the emission process and the subsequent transport of mineral dust and volcanic ash over complex terrain. In the present study, the modeling follows three consecutive steps: (i) numerical weather prediction (NWP) model run, (ii) calculation of dust emission rates, and (iii) dispersal model run.

In the first step, we run the WRF-ARW meteorological model with three nested domains in order to downscale the physical properties of the atmosphere to a spatial resolution of $2 \mathrm{~km}$ to obtain a reliable background to drive the dust model. The dust emission rates are calculated from the downscaled WRF atmospheric and soil fields. The sensitivity of simulated mineral dust emission to meteorological field resolution is evaluated at this stage. Finally, the evolution of the dust cloud is modeled with the dispersal model.

\subsection{Meteorological model}

In this study, the meteorological fields were simulated with the WRF-ARW (version 3.4). A detailed description of the
Table 1. WRF-ARW configuration.

\begin{tabular}{|c|c|}
\hline Parameter & Value \\
\hline \multicolumn{2}{|c|}{ Input data: } \\
\hline Terrain and land use & USGS $^{\mathrm{a}}$ \\
\hline Initial and boundary & ERA-Interim ${ }^{\mathrm{b}}$ \\
\hline Temporal interval of boundary & $6 \mathrm{~h}$ \\
\hline \multicolumn{2}{|c|}{ Time control: } \\
\hline Start & 13 June, 00:00 UTC \\
\hline End & 14 June, 06:00 UTC \\
\hline \multicolumn{2}{|c|}{ Domains: } \\
\hline Map projection & Lambert conformal \\
\hline Nesting & Two-way (multiple input files) \\
\hline Spatial resolution & 18,6 , and $2 \mathrm{~km}$ \\
\hline Vertical levels & 60 \\
\hline Temporal resolution & Adaptive time step \\
\hline Minimum time step (s) & $\Delta x(\mathrm{~km})^{\mathrm{c}}$ \\
\hline Maximum time step (s) & $6 \times \Delta x(\mathrm{~km})^{\mathrm{c}}$ \\
\hline \multicolumn{2}{|c|}{ Physics: } \\
\hline PBL scheme ${ }^{\mathrm{d}}$ & Mellor-Yamada-Janjić \\
\hline Surface & Noah Land Surface Model \\
\hline Surface layer physics & Eta similarity \\
\hline Microphysics & Eta (Ferrier) \\
\hline Short-wave radiation & Dudhia scheme \\
\hline Long-wave radiation & RRTM scheme \\
\hline \multicolumn{2}{|c|}{ Dynamics: } \\
\hline Dynamics & Nonhydrostatic \\
\hline Time integration & Runge-Kutta third order \\
\hline Turbulence and mixing & Second-order diffusion on model levels \\
\hline Eddy coefficient & 2-D Smagorinsky \\
\hline Horizontal momentum advection & Fifth order \\
\hline Vertical momentum advection & Third order \\
\hline \multicolumn{2}{|c|}{$\begin{array}{l}\text { Static data from the US Geological Survey (USGS): 24-category USGS-based land use and } \\
\text { topography data from the USGS } 30 \text { arcsec resolution global dataset (GTOPO30). }\end{array}$} \\
\hline \multicolumn{2}{|c|}{$\begin{array}{l}\text { CenA-Interim reanalysis data (model levels and surface) obtained from the ECMWF (European } \\
\text { Center for Medium-range Weather Forecasts). } \\
\text { c } \Delta x \text { : horizontal spatial resolution of the grid domain. }\end{array}$} \\
\hline Planetary boundary layer scheme (see Skan & arock et al., 2008, for further details). \\
\hline
\end{tabular}

WRF-ARW is available in Skamarock et al. (2008). The WRF model configuration used is presented in Table 1.

We used 6-hourly ERA-Interim reanalysis data with spatial resolution of approximately $0.75^{\circ} \times 0.75^{\circ}$ and 60 vertical levels from ground to $0.1 \mathrm{hPa}$, obtained from the ECMWF (European Center for Medium-range Weather Forecasts) (Dee et al., 2011) as initial meteorological field for the WRF domains and boundary condition for the coarsest domain.

Friction velocity and soil moisture content are relevant fields for the dust model obtained from the WRF output (see Sect. 3.2.1). The friction velocity, $u_{*}$, is an important scaling variable in the similarity theory (Monin and Obukhov, 1954; Janjic, 1996) related to wind shear near the surface and is defined as

$u_{*}=\sqrt{\frac{|\tau|}{\rho}}$,

where $\tau$ is the surface Reynold's stress and $\rho$ the density (Stull, 1988). The friction velocity is calculated by the Eta surface layer scheme, which is based on the similarity theory. 
The representation of land processes is achieved by coupling the WRF model with a land surface scheme, which provides heat and moisture fluxes over land surface to the parent atmospheric model. We use the Noah land surface model, a multilayer soil model using four soil layers with thicknesses of $10,30,60$, and $100 \mathrm{~cm}$. It solves vertical soil water transport using the diffusive form of Richard's equation to predict the volumetric soil moisture, i.e., the fraction of total volume of moist soil occupied by water in $\mathrm{m}^{3} \mathrm{~m}^{-3}$, in every layer (Chen and Dudhia, 2001).

A satisfactory description of the transport of aerosols depends on an accurate representation of the planetary boundary layer (PBL) (Banks et al., 2016). The numerical experiments are conducted with a local closure PBL scheme implemented by Mellor-Yamada-Janjić (MYJ) (Janjic, 1994). The surface schemes calculate the surface fluxes of momentum, moisture, and heat and provide a lower boundary condition for the PBL scheme (Skamarock et al., 2008).

\subsection{Dispersal model}

The simulations were conducted coupling the WRF model to the FALL3D dispersal model, version 7.0 (Costa et al., 2006; Folch et al., 2009). FALL3D is an Eulerian model for transport and deposition of volcanic ash particles. The model solves the advection-diffusion-sedimentation equations in a curvilinear terrain-following coordinate system using a second-order finite differences explicit scheme. The FALL3D model follows an offline strategy; i.e., a meteorological model provides the meteorological fields a priori.

The diagonal components of the eddy diffusivity tensor, required for the evaluation of kinematic turbulent fluxes, have been parametrized using the similarity theory option (Ulke, 2000) for the vertical component and the CMAQ (Community Multiscale Air Quality) model option (Byun and Schere, 2006) for the horizontal diffusion. The parametrization of the Ganser model (Ganser, 1993) is used to compute the particle settling velocity.

\subsubsection{Dust emission scheme}

The emission rate of windblown dust depends on the transfer of the wind energy to the erodible surface (Marticorena and Bergametti, 1995). Usually, the dust flux is modeled using the friction velocity $\left(u_{*}\right)$ concept (see Sect. 3.1). The minimum friction velocity necessary to initialize the movement of soil particles is called threshold friction velocity, $u_{* \mathrm{t}}$. The motion of soil particles by wind depends on particle size, $d$, and wind speed. Models of dust emission distinguish two major modes of airborne particle motion, namely, suspension and saltation (Bagnold, 1941; Greeley and Iversen, 1985). Suspension refers to the floating motion of airborne fine particles (typically, $d \lesssim 70 \mu \mathrm{m}$ ) (Shao, 2008). These particles can remain in the atmosphere for long times and be transported over hundreds of kilometers within the atmosphere because of their small terminal velocities. Saltation is the most common form of aeolian sand transport. It refers to the hopping motion of sand particles (typically, $d \sim 70-500 \mu \mathrm{m}$ ) along the ground surface in the direction of the wind (Shao, 2008).

The Fall3D model in resuspension mode (Folch et al., 2014) includes three different emission schemes (of increasing sophistication) that are applied to the case of volcanic ash, although they have been developed theoretically or calibrated experimentally for mineral dust: (i) Westphal scheme (Westphal et al., 1987), (ii) Marticorena and Bergametti scheme (Marticorena and Bergametti, 1995; Marticorena et al., 1997), and (iii) Shao scheme (Shao et al., 1993; Shao and Leslie, 1997; Shao and Lu, 2000).

In this work, we use the Shao scheme as is described by Folch et al. (2014) with minor modifications. The theory for dust emission by Shao et al. (1993) is based on a hypothesis about the energetics of dust emission and considers particle-particle interaction by saltation bombardment (see Folch et al., 2014, for more details). This parametrization depends crucially on deposit characteristics such as particle size distribution, thickness, and particle density and requires reliable input data. The parametrizations used to model the emission flux of dust are detailed below.

\section{Vertical flux}

According to the wind tunnel experiments conducted by Shao et al. (1993), saltation bombardment is the principal mechanism for the ejection of dust particles and the influence of aerodynamic lift on dust is insignificant under realistic meteorological conditions (Shao, 2008). Therefore, some theoretical models have assumed that the vertical flux of dust emitted is proportional to the horizontal saltation flux (Marticorena and Bergametti, 1995; Shao et al., 1996).

The vertically integrated streamwise saltation flux $Q$ $\left(\mathrm{kg} \mathrm{m}^{-1} \mathrm{~s}^{-1}\right)$ is calculated in this paper using the expression suggested by Owen (1964) for the case of saltating particles of size $d_{\mathrm{s}}$ :

$Q\left(d_{\mathrm{s}}\right)=\frac{c \rho u_{*}^{3}}{g}\left[1-\left(\frac{u_{* \mathrm{t}}\left(d_{\mathrm{s}}\right)}{u_{*}}\right)^{2}\right], \quad u_{*} \geq u_{* \mathrm{t}}$,

where $c$ is a dimensionless coefficient of order unity, $\rho$ is air density, and $g$ is gravitational acceleration.

Based on theoretical and experimental results, Shao et al. (1993) found an expression for the vertical flux of dust particles of size $d$ ejected by saltation bombardment of saltating particles of size $d_{s}$ :

$F_{\mathrm{V}}\left(d, d_{\mathrm{s}}\right)=\frac{\alpha\left(d, d_{\mathrm{s}}\right)}{u_{* \mathrm{t}}^{2}(d)} Q\left(d_{\mathrm{s}}\right), \quad d_{\mathrm{s}} \geq d$,

where $F_{\mathrm{V}}$ has the dimension of $\mathrm{kg} \mathrm{m}^{-2} \mathrm{~s}^{-1}$ and $\alpha\left(\mathrm{ms}^{-2}\right)$ is a parameter associated to the efficiency of saltation bombardment. We used the experimentally obtained expression given 
by (Shao and Leslie, 1997)

$\alpha\left(d, d_{\mathrm{s}}\right)=\left[0.6 \log \left(d_{\mathrm{s}}\right)+1.6\right] \exp (-140 d)$,

with $d$ and $d_{\mathrm{s}}$ in millimeters.

We assume a grain size distribution discretized in a group of particle classes. A class of particles of size $d$ is characterized by a mass fraction $p(d)$ satisfying $\sum p(d)=1$. For soils with multiparticle sizes, the dust flux can be estimated from the discretized grain size distribution as a sum (Shao and Leslie, 1997):

$F_{\mathrm{V}}(d)=\sum_{d_{\mathrm{s}}=d}^{d_{\mathrm{s}}=d_{\max }} \frac{\alpha\left(d, d_{\mathrm{s}}\right)}{u_{* \mathrm{t}}^{2}(d)} p(d) p\left(d_{\mathrm{s}}\right) Q\left(d_{\mathrm{s}}\right)$.

Most of dust models consider a dust size range with maximum diameter between 40 and $76 \mu \mathrm{m}$ (Uno et al., 2006). However, larger particles can be transported by wind over significant distances. As an example, measurements of particle size distribution for volcanic ash in Iceland showed that ash particles as large as $177 \mu \mathrm{m}$ can be remobilized over several hundred kilometers (Liu et al., 2014). The authors mention that most of the mass was contained within the $32-63 \mu \mathrm{m}$ size fraction. In this paper, the source term for the dispersion model was calculated using Eq. (5) for particle sizes $d<60 \mu \mathrm{m}$.

\section{Threshold friction velocity}

The threshold friction velocity represents the resistance of the surface against wind erosion. In this study, we use the expression of the threshold friction velocity for spherical particles loosely spread over a dry and bare surface derived by Shao and Lu (2000):

$u_{* \mathrm{t}}^{o}(d)=\sqrt{0.0123\left(\frac{\rho_{\mathrm{p}} g d}{\rho}+\frac{\gamma}{\rho d}\right)}$,

where $\rho_{\mathrm{p}}$ is the particle density, $\rho$ is the air density, and $g$ is the gravitational acceleration. The experimental parameter $\gamma \approx 3 \times 10^{-4} \mathrm{~kg} \mathrm{~s}^{-2}$ takes into account the effect of interparticle cohesion.

Additionally, inter-particle cohesion also depends on soil moisture content. In order to take into account this effect, the threshold friction velocity $u_{* \mathrm{t}}$ is expressed as

$u_{* \mathrm{t}}=u_{* \mathrm{t}}^{\mathrm{o}}(d) f(w)$

where $f(w)$ is a moisture correction and $w$ is the gravimetric soil moisture, i.e., the water content of a soil sample expressed as a percent of the oven-dry mass of the sample.
For the moisture correction, we used the following empirical expression obtained by Fécan et al. (1999):

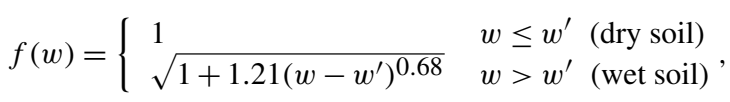

where $w^{\prime}$ is the maximum amount of adsorbed water. It depends on the soil texture, is negligible for sands, and increases with the soil clay content. In this work, $w^{\prime}=1 \%$ is assumed.

Other factors, e.g., nonerodible surface roughness elements, may have a significant influence on the threshold friction velocity, but they are not considered here.

\section{The dust outbreak on 13 June 2015}

Episodes of strong dusty winds in Fiambalá throughout 2015 were reported by local media in July, August, September, and October. Dusty winds with gusts of up to $90 \mathrm{~km} \mathrm{~h}^{-1}$ caused a range of problems, such as trees down, power outages by falling utility poles, roofs blown off, fires, road transport disruption due to poor visibility, and widespread crop injury. Remarkably, local media did not report any event on 13 June.

Prevailing winds in the region are southerly and southeasterly, although in austral winter, strong warm and very dry northerly and northwesterly winds, often carrying dust, are occasionally observed. Zonda wind is the regional term for this kind of wind that often occurs on the eastern slope of the Andes in Argentina. When intense winds in a stable environment reach a mountain range they can produce mountain waves and descending warm and dry leeward winds. These kinds of winds are usually named depending on the region that they occur: for example, foehn in central Europe (Germany, Austria, Switzerland) (Fleagle, 1950; Klemp and Lilly, 1975), chinook in Canada and the United States east of the Rocky Mountains (Brinkmann, 1974), Canterburynor'wester in New Zealand (Lamb, 1974), berg wind in South Africa (Lindesay and Tyson, 1990), and zonda wind in Argentina (Norte, 1988) to the east of the Andes mountain range (Seluchi et al., 2003). Severe cases of the zonda near the Andes often occur in winter and spring seasons. Warm, dry, and gusty winds experienced during zonda events can lift and transport large amounts of dust as they reach the east side of the Andes (Allende et al., 2012; Norte, 2015).

Observations on 13 June exhibit the signatures of a zonda episode in the study region. Figure 2 shows measurements of temperature $(T)$, dew point temperature $\left(T_{\mathrm{D}}\right)$, and surface wind speed from an automatic weather station from the $\mathrm{Na}$ tional Weather Service of Argentina at Catamarca Airport $\left(27^{\circ} 4^{\prime} 36^{\prime \prime} \mathrm{S}-66^{\circ} 35^{\prime} 37^{\prime \prime} \mathrm{W}\right.$; altitude: $\left.2308 \mathrm{~m}\right), 120 \mathrm{~km}$ from the Fiambalá Basin (see Fig. 1). The automatic weather station measured a strong reduction in relative humidity (sudden decrease in $T_{\mathrm{D}}$ and increase in $T$ ) from 03:00 until 20:00 UTC, and a strong increase in wind speed, with a maximum speed of almost $35 \mathrm{kt}$ in the NW direction registered 


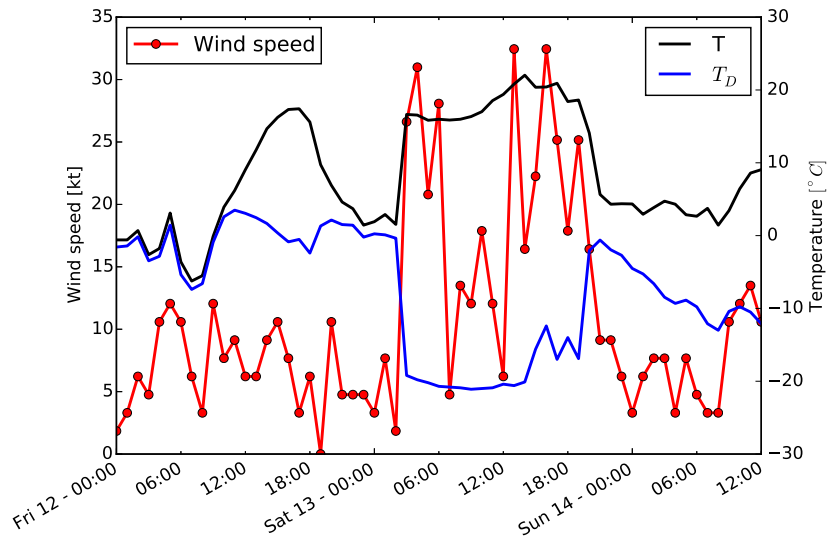

Figure 2. Measurements from an automatic weather station from the National Weather Service of Argentina at Catamarca Airport, $120 \mathrm{~km}$ from the Fiambalá Basin. Wind speed (red line with circle markers), temperature ( $T$, black line), and dew point temperature ( $T_{D}$, blue line). The signatures of a zonda episode, i.e., warm, dry, and windy conditions, are observed on 13 June.

around 15:00 UTC (Fig. 2). According to the GOES-13 water vapor imagery, the dry signature associated with strong subsidence at the lee side of the Andes mountains in northwestern Argentina is observed during 13 June in accordance to the zonda event (see the animation in Supplement). Particularly, the image at 15:00 UTC of 13 June shows a dry zone and a series of trapped lee waves.

\subsection{Satellite imagery}

A dust plume was identified using the RGB dust product from the SEVIRI instrument, on board the MSG satellites. The dust product is an RGB (red-green-blue) composite based on infrared channels, which allows suspended dust to be detected during both the day and nighttime. The RGB composite is produced using the band differences IR12.0IR10.8 (on red), IR10.8-IR8.7 (on green), and the IR10.8 channel (on blue) (Banks and Brindley, 2013). In the RGB combination, dust appears pink or magenta, a result of the high contrast between the brightness temperatures at the 12 and $10.8 \mu \mathrm{m}$ channels. Thick high-level clouds have redbrown tones and thin high-level clouds appear very dark (nearly black).

Figure 3 shows the satellite imagery on 13 June and early morning hours of 14 June. The dust outbreak affected the northern part of Argentina with dust aerosols from the Fiambalá Basin detected from 14:00 UTC by the RGB dust product. For the sake of clarity, the dust clouds are surrounded by black dashed lines. The emitted dust was initially transported southeastwards (Fig. 3) over Catamarca province (see Fig. 1). Subsequently, westerly winds advected the dust aerosols towards the east of Argentina over the provinces of Santiago del Estero and Santa Fé. During the early morning
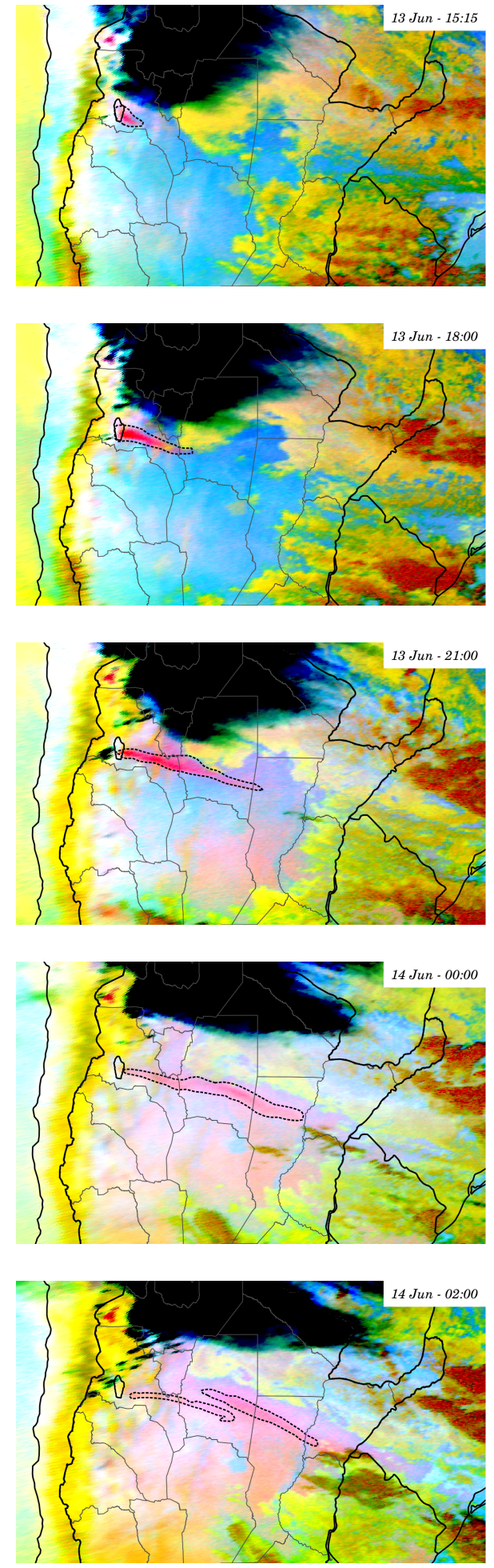

Figure 3. Dust detection with the MSG-SEVIRI RGB Product at 15:15, 18:00, 21:00 (13 June), 00:00, and 02:00 UTC (14 June). The dust cloud (black dashed line) moved southeastwards across northern Argentina. The dark spots on the top of the figures represent meteorological clouds affecting parts of Argentina, Bolivia, Paraguay, and Chile. 
(a)

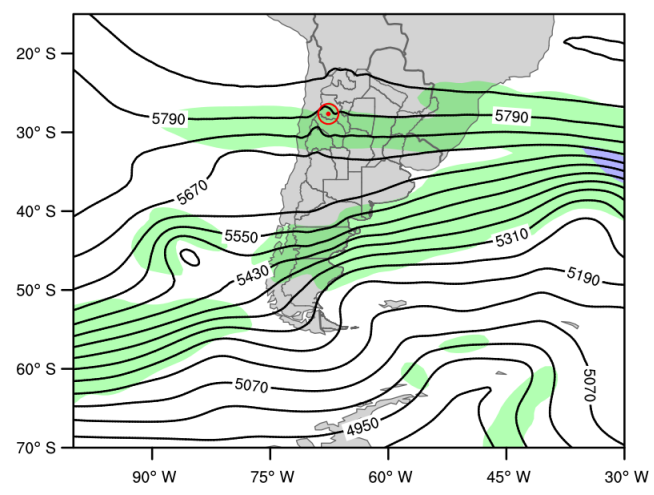

(b)

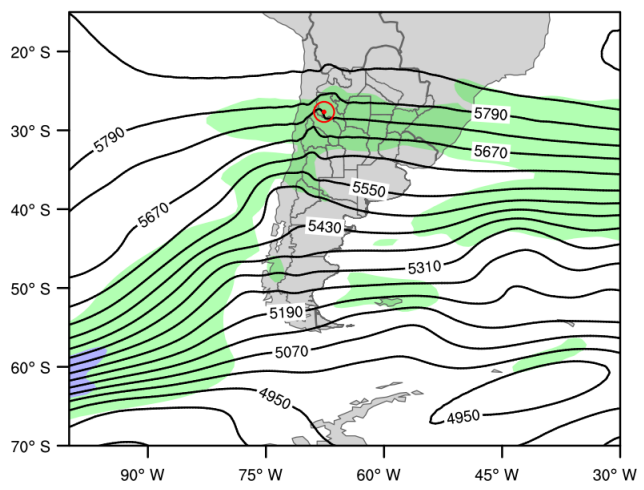

Figure 4. Meteorological situation corresponding to 12:00 UTC on 12 June 2015 (a) and 12:00 UTC on 13 June 2015 (b). Solid line: the $500 \mathrm{hPa}$ geopotential height $(\mathrm{gpm})$. Shaded green contour: wind speed $>24 \mathrm{~m} \mathrm{~s}^{-1}$. Shaded blue contour: wind speed $>48 \mathrm{~m} \mathrm{~s}{ }^{-1}$. Fiambalá location is stated by a red circle. Dataset from ERA-Interim reanalysis.

hours of 14 June the more diffused cloud became difficult to identify. When the detection becomes more difficult, the cloud tracking is conducted by comparing images at different times to determine the dust contour (black dashed lines). It should be noted that the images are characterized by meteorological clouds dominating northern Argentina (dark spot on the top of the figures).

\subsection{Reanalysis dataset - synoptic situation}

Figure 4 shows the synoptic situation on 12 and 13 June, both at 12:00 UTC, according to reanalysis data from ECMWF (Dee et al., 2011). The green shaded area in Fig. 4 denotes the region with wind speeds at $500 \mathrm{hPa}$ above $24 \mathrm{~m} \mathrm{~s}^{-1}$. On 12 June, at $500 \mathrm{hPa}$ a cyclonic center located at $85^{\circ} \mathrm{W}$ over the Pacific Ocean propagates northeastwards (Fig. 4a). A surface cyclone centered around $55^{\circ} \mathrm{S}, 60^{\circ} \mathrm{W}$, over the Atlantic Ocean, and an associated cold front that crosses along the south of Patagonia was observed. In addition, the frontal cloudiness can be observed in satellite images (see the animation in Supplement). The following day (13 June) at 12:00 UTC the surface cyclonic center had propagated eastwards, the frontal zone reached the north of the Patagonia region, and a mid-level well-developed trough, located over the Pacific ocean, with strong horizontal pressure gradient produced an increase in horizontal wind speeds over the zone of study (Fig. 4b).

Prevailing westerly winds in the upper troposphere intensify on 13 June above the region of study regarding the previous days because the subtropical jet stream shifts equatorward. In Fig. 5 the Fiambalá location is marked by a red circle in a meridional cross section of zonal wind on 13 June at 18:00 UTC. The subtropical jet stream core at $250 \mathrm{hPa}$ is located close to latitude $30^{\circ} \mathrm{S}$, above the region of study.

In summary, the synoptic key features that produce zonda events (Seluchi et al., 2003; Norte, 2015) are present in this case of study: a mid-level trough west of the Andes, a sur-

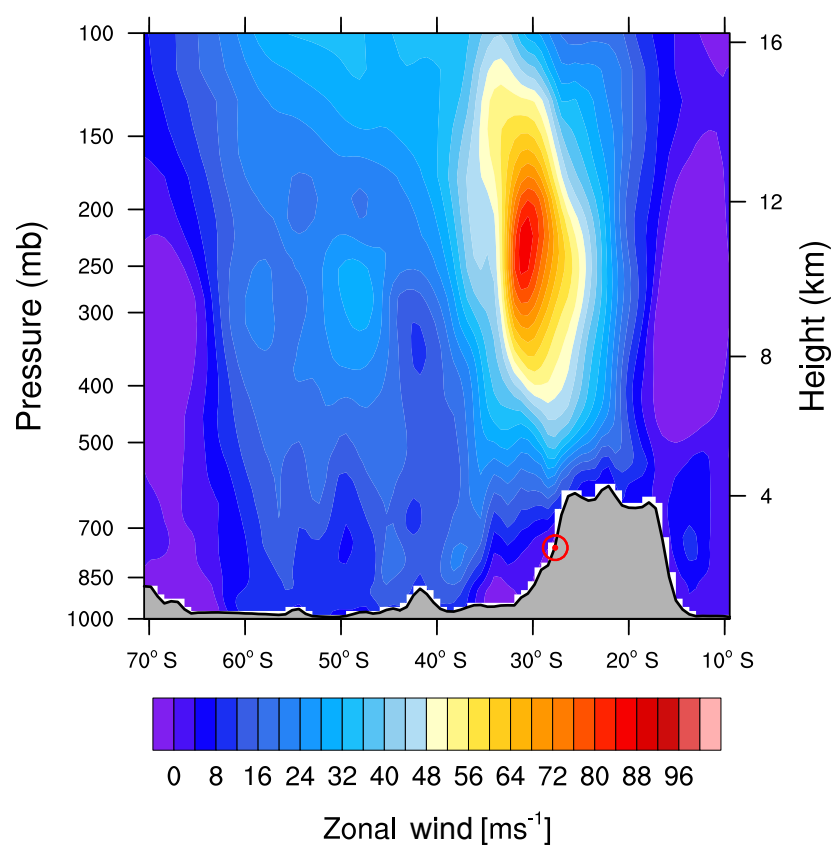

Figure 5. Meridional cross section of zonal wind along the Fiambalá longitude on 13 June at 18:00 UTC. The subtropical jet stream core at $250 \mathrm{hPa}$ shifts equatorward, reaching the Fiambalá latitude (stated by a red circle). Dataset from ERA-Interim reanalysis.

face cyclone southeast of the barrier near the extreme of the continent, a jet stream located over the region of study, and the frontal zone over the northern regions of Patagonia.

\subsection{Reanalysis dataset - June time series}

The ERA-Interim dataset for June 2015 was analyzed to ascertain the exceptional conditions that occurred on 13 June. Figure 6 shows the time series throughout June for relevant variables at Fiambalá location. The wind speed at $500 \mathrm{hPa}$ 


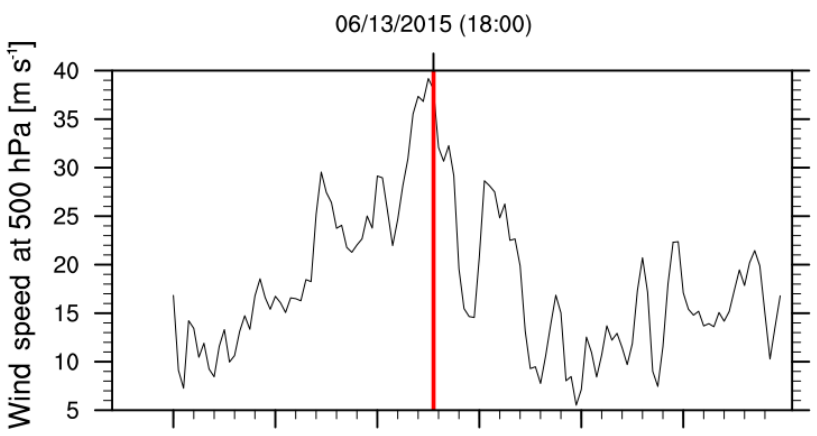

(a)

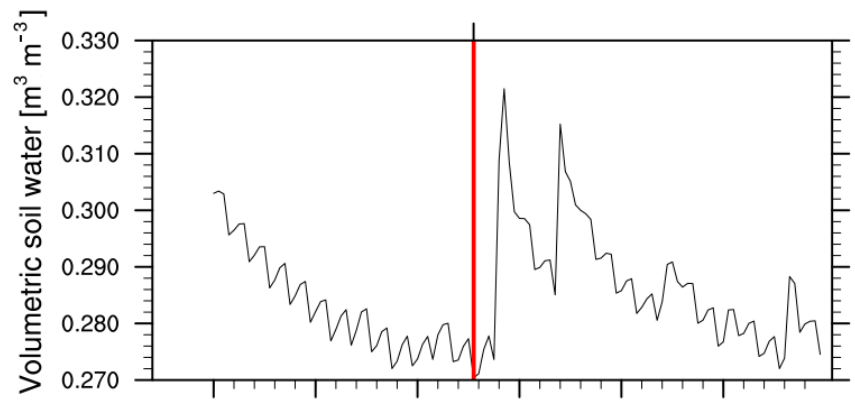

(b)

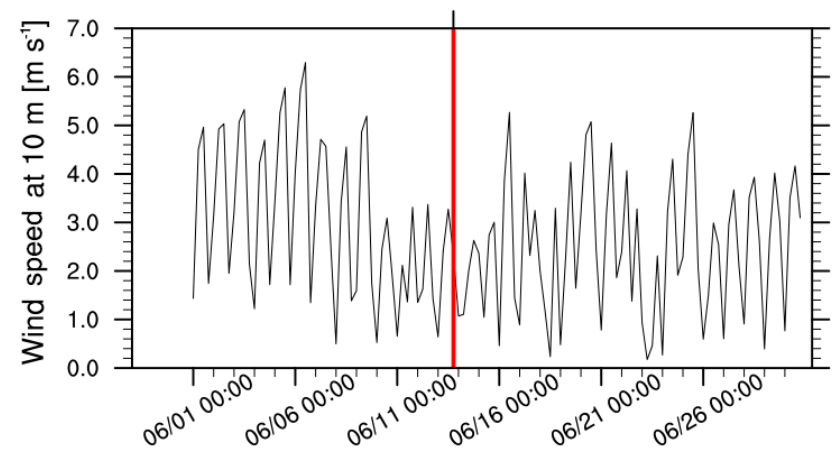

(c)

Figure 6. Time series at Fiambalá coordinates during June for wind speed at $500 \mathrm{hPa}(\mathbf{a})$, volumetric soil water (b), and wind speed at $10 \mathrm{~m}$ (c). The conditions on 13 June at 18:00 UTC (red line) allowed dust to be raised in suspension in the atmosphere. Dataset from ERA-Interim reanalysis.

(Fig. 6a) shows a peak on 13 June (see the reference line at 18:00 UTC). Figure 6b suggests that dry soil conditions could create favorable conditions for dust mobilization, as the lowest volumetric soil moisture in June occurred on 13th.

Remarkably, the surface wind speed on 13 June did not exceed the June 2015 average (Fig. 6c), suggesting that highresolution simulations are required to explain the dust outbreak. In the next section is carried out a thorough study of the key role played by terrain-induced mesoscale disturbances of the large-scale prevailing flows.

\section{Results and discussion}

\subsection{Domain configuration}

The WRF model was integrated up to $54 \mathrm{~h}$ with the initial conditions at 00:00 UTC on 12 June, considering the first 12$\mathrm{h}$ period for model spin-up. In the vertical, 60 levels were set with model top at $50 \mathrm{hPa}$.

Figure $7 \mathrm{a}$ shows the domain configuration. It consists of three two-way nested domains with grid sizes of 18,6 , and $2 \mathrm{~km}$ for domains $\mathrm{d} 01, \mathrm{~d} 02$, and $\mathrm{d} 03$, respectively. The twoway nesting approach implies that each inner grid domain receives boundary conditions from a coarser (parent) domain and the exchange of information between the parent and the nest is bidirectional (Jacobson, 2005). The coarsest domain covered the northern Argentina. The $6 \mathrm{~km}$ domain covered northwestern Argentina including the complex topography of the Andes mountain range. The finest $2 \mathrm{~km}$ domain covered the Fiambalá Basin. In each case, the domains are centered at $27.5^{\circ} \mathrm{S}, 67.7^{\circ} \mathrm{W}$, i.e., the coordinates of Fiambalá, approximately.

The topography data were obtained from the US Geological Survey (USGS) global 30 arcsec elevation dataset. The terrain heights around the Fiambalá Basin for the three nested domains are shown in Fig. 7b, c, and d. The solid lines in these figures delimit the Fiambalá Basin and define the area of potential dust sources in our modeling strategy.

The importance of the horizontal resolution for a proper representation of the orographic features of the region becomes evident in these figures. Particularly, Fig. $7 \mathrm{~d}$ shows an extremely abrupt terrain for the $2 \mathrm{~km}$ domain with variations in terrain height between 6000 and $700 \mathrm{~m}$.

Due to strong vertical wind velocities in steep terrain, the model develops numerical instability for a large enough time step. For WRF-ARW, the time step (in seconds) should typically be about $6 \times \Delta x$, with the grid spacing, $\Delta x$, in kilometers. However, we found that time steps greater than $\sim 3 \times \Delta x$ triggered violations of the Courant-Friedrichs-Lewy (CFL) condition. In this work, we used the adaptive time step option to avoid CFL instabilities.

The WRF-ARW fields (on a Lambert conformal projection) were interpolated onto the FALL3D regular lat-long grid by bilinear interpolation. The FALL3D model was run using two domains: (a) the fine domain with $0.01^{\circ}$ grid resolution, centered over the Fiambalá Basin, and (b) the coarse domain with $0.1^{\circ}$ grid resolution, covering the northern part of Argentina. The fine-resolution domain spans from 28 to $27^{\circ} \mathrm{S}$ in latitude and from 68 to $67.3^{\circ} \mathrm{W}$ in longitude, whereas the coarse domain spans from 32 to $22^{\circ} \mathrm{S}$ in latitude and from 72 to $56.8^{\circ} \mathrm{W}$ in longitude. In both cases 57 vertical levels up to $8.5 \mathrm{~km}$ a.g.l. (above ground level) were used. We run FALL3D on the fine and coarse domains to simulate the short- and long-range transport of mineral dust, respectively. 
(a)

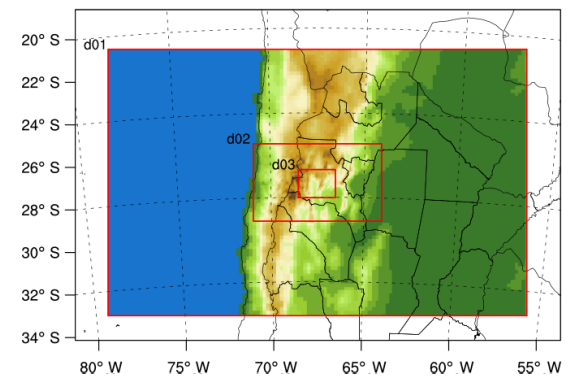

(b)

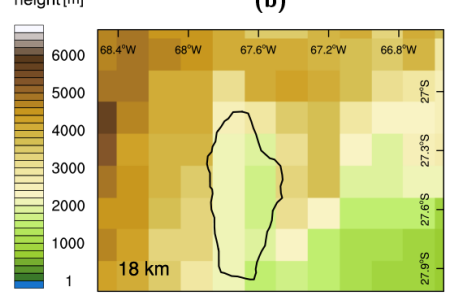

(c)

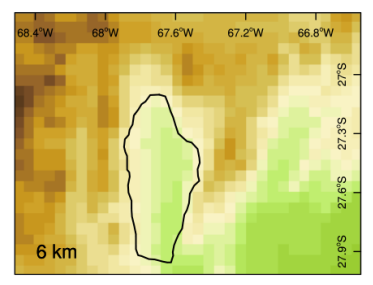

(d)

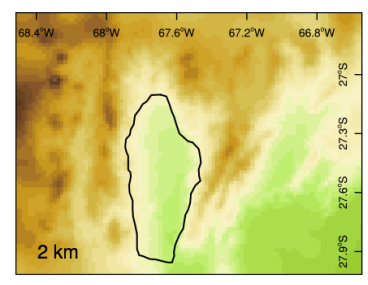

Figure 7. WRF model domain configuration. The colors indicate the model terrain height. Three two-way nested domains enclosing the Fiambalá Basin with horizontal resolutions are 18,6, and $2 \mathrm{~km}$, from the parent to the innermost domain, respectively (a). Terrain height around the Fiambalá Basin for the $18 \mathrm{~km}(\mathbf{b}), 6 \mathrm{~km}(\mathbf{c})$, and $2 \mathrm{~km}(\mathbf{d})$ domains. The Fiambala Basin is defined by the outlined region (black line). Topography data from the US Geological Survey (USGS).

\subsection{Zonda episode}

According to simulations, the surface wind intensified significantly on 13 June. Figure 8 shows horizontal wind vectors at $10 \mathrm{~m}$ above the ground simulated by the WRF model for the $2 \mathrm{~km}$ innermost domain. Light winds dominated the Fiambalá Basin during 12 June (Fig. 8a). On 13 June, the presence of a zonda wind caused strong downslope winds in northern Fiambalá Basin (Fig. 8b). In the figure we identify the geographic location $P\left(27.25^{\circ} \mathrm{S}, 67.7^{\circ} \mathrm{W}\right)$ in northern Fiambalá Basin, as a reference. The maximum mean wind speed at $P$, reached at 15:00 UTC on 13 June, was about $20 \mathrm{~m} \mathrm{~s}^{-1}$ blowing from the NE direction.

The mountain waves that accompany zonda events can be recognized in this case. Figure 9a shows a vertical cross section of equivalent potential temperature (or theta- $e$ ) and vertical wind velocity through the Andes at the latitude of $P$ $\left(27.25^{\circ} \mathrm{S}\right)$. The theta- $e$ contours show an unstable layer near the surface on the windward side. At the top of the mountain a stable layer was observed that will remain during the whole period of study. Above the Fiambalá Basin ( $P$ in Fig. 9a), on the lee side, the troposphere is less stable with strongly tilting isentropes and descending airflow at all levels. The skew- $T$ diagram at $P$ shows other typical characteristics of a zonda episode (Fig. 9b): a very dry air column at all levels and a nearly dry adiabatic lapse rate at low levels, suggesting subsidence reaches the surface (Seluchi et al., 2003). The emergence of a descending air mass becomes evident in the time series of the vertical wind speed $(W)$ at $P$ (Fig. 9c). According to the simulations, there is a vertical downward wind speed from 13 June at 00:00 UTC until 14 June at 00:00 UTC, approximately. The time series of the temperature $(T)$ and the dew point temperature $\left(T_{\mathrm{D}}\right)$ at $P$ show a strong reduction in relative humidity, compatible with the presence of a zonda wind, throughout 13 June. Notice that the WRF time series for $T$ and $T_{\mathrm{D}}$ are similar to measurements at Catamarca station (Fig. 2). (a)

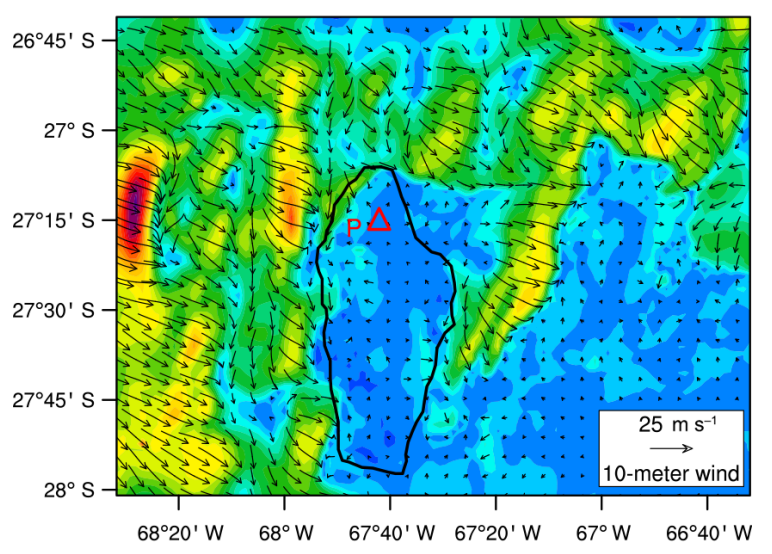

(b)

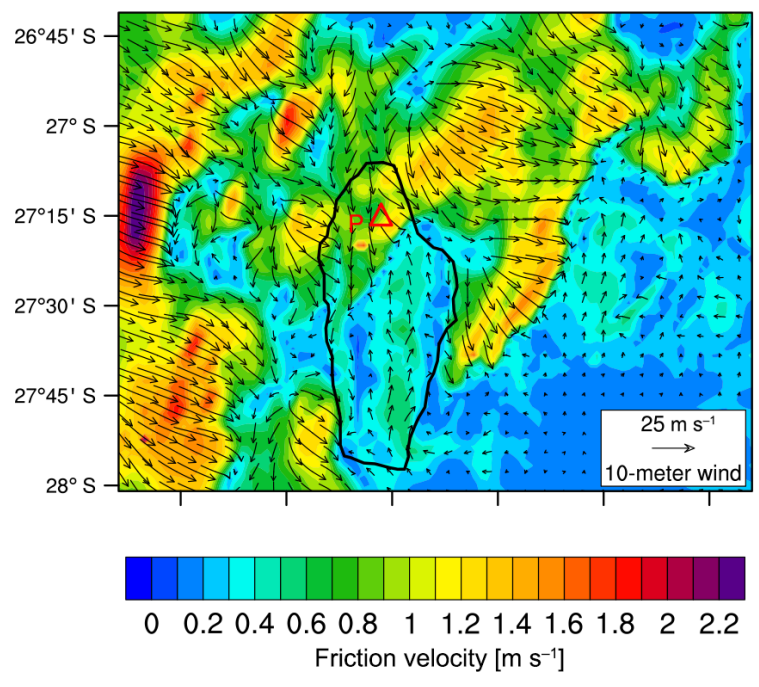

Figure 8. Friction velocity contours and wind vectors at $10 \mathrm{~m}$ above the surface simulated by WRF model for the $2 \mathrm{~km}$ innermost domain at 15:00 UTC on 12 June (a) and 15:00 UTC on 13 June (b). The Fiambalá Basin is defined by the outlined region (black line). We identify the geographic location $P$ for future reference. 
(a)

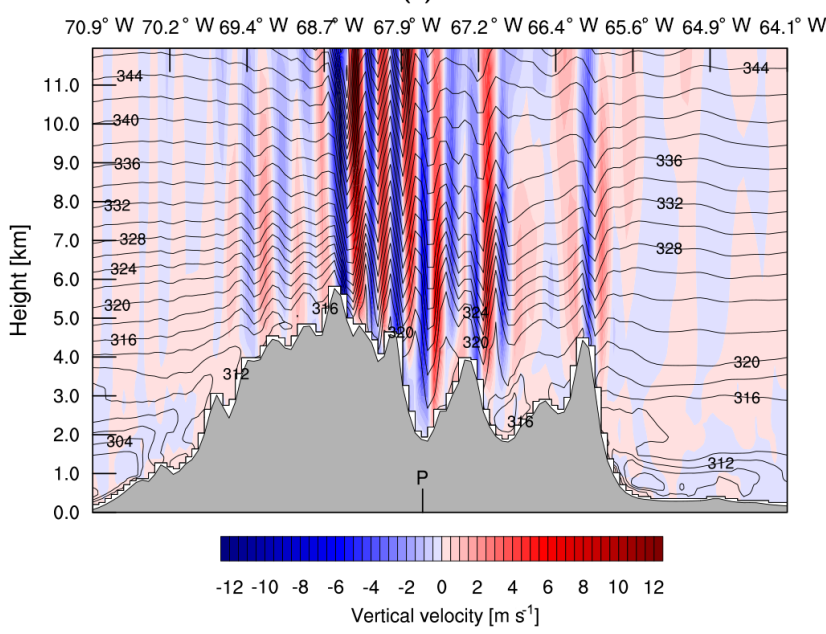

(b)

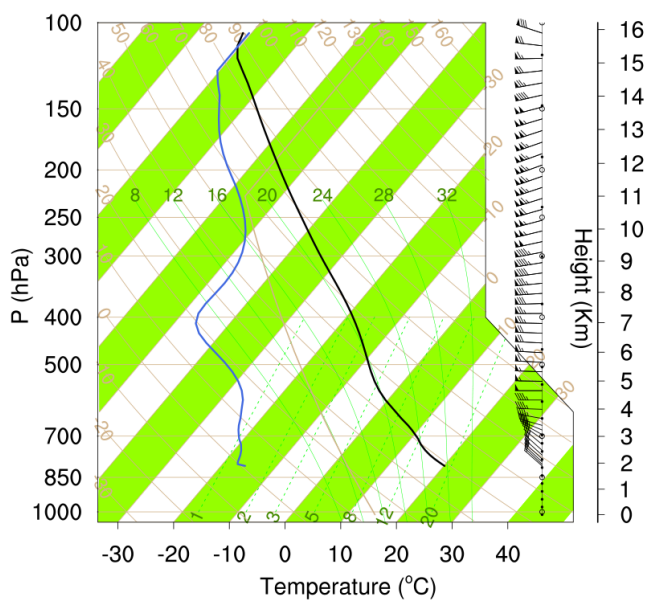

(c)

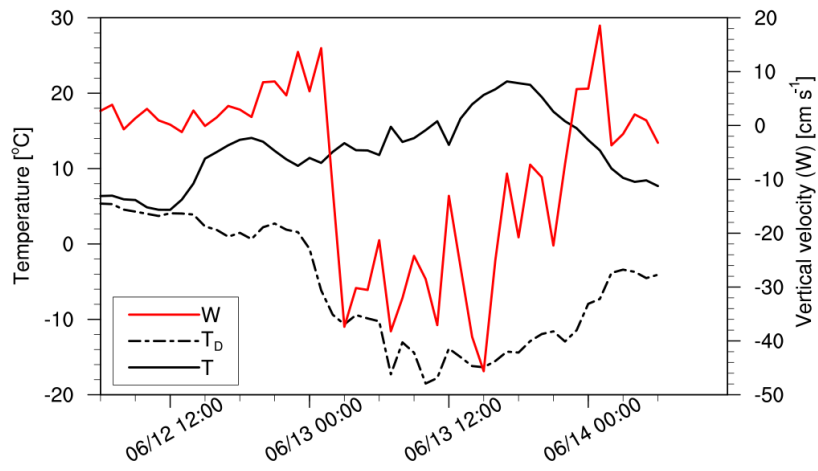

Figure 9. Features of a zonda event in the northern Fiambalá Basin according to WRF-ARW output. (a) Vertical cross section of equivalent potential temperature $(\mathrm{K})$ and vertical wind velocity $\left(\mathrm{m} \mathrm{s}^{-1}\right)$ through the Andes along the latitude of $P\left(27.25^{\circ} \mathrm{S}\right)$ at 16:00 UTC on 13 June. (b) Skew- $T$ log- $P$ diagrams at $P\left(27.25^{\circ} \mathrm{S}, 67.7^{\circ} \mathrm{W}\right)$ at 16:00 UTC on 13 June. (c) Time series at $P$ for temperature $(T)$, dew point temperature $\left(T_{\mathrm{D}}\right)$, and vertical velocity $(W)$. Temperatures at $2 \mathrm{~m}$ and vertical wind velocity at the first model level $(\sim 27.5 \mathrm{~m})$.

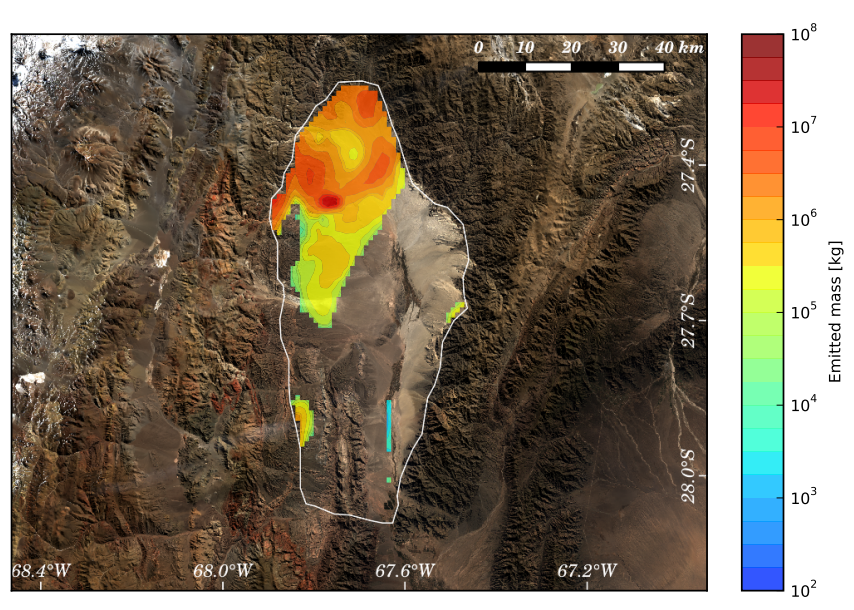

Figure 10. Grid emitted mass throughout the $54 \mathrm{~h}$ simulation according to the Shao emission scheme using meteorological data from the innermost domain $\mathrm{d} 03(2 \mathrm{~km})$. We assume that dust emission takes place only within the spatial region defined by the solid white line delimiting the Fiambalá Basin. In the background, a Landsat-8 image acquired on 14 June 2015.

\subsection{Source strength}

The emission rates are obtained as a preprocessing step by the FALL3D dispersal model using the emission scheme proposed by Shao and Leslie (1997) (Shao scheme). The vertical flux of dust, Eq. (5), is calculated on the FALL3D fine domain with $0.01^{\circ}$ grid resolution (see Sect. 5.1). Since the WRF-ARW fields were interpolated onto the same FALL3D grid, results obtained using meteorological data at different resolutions can be compared.

We have no accurate information on the distribution of deposits in this region. Consequently, we consider that the emission area is delimited by the solid line in Fig. 7, defined approximately by the terrain height contour of $2000 \mathrm{~m}$. This area represents properly the origin of the dust cloud detected by satellite imagery (Fig. 3). In our modeling strategy, dust emission is assumed to take place within the spatial region determined by the solid line, with no emission occurring outside (see Fig. 10).

The elevation at which dust aerosols are injected into the atmosphere has a strong influence on the subsequent transport. The initial height for the emitted dust (injection height) is highly uncertain in numerical models (Darmenov, 2009). For example, Park et al. (2007) considered two injection schemes depending on whether the mass is injected in the first model layer (one-layer injection) or in the lowest three layers (three-layer injection). The author suggested that the one-layer injection scheme can significantly underestimate the amount of dust transported. Conversely, the injection height in the CFORS regional model (Uno et al., 2003) is determined from the vertical profile of the potential temperature. In this study, the time-dependent source term is ob- 
tained assuming a uniform vertical distribution of the emitted mass up to a fixed injection height. We assume that the mass is injected between the two lowest layers (top layer height: $235 \mathrm{~m}$ a.g.1.) of the FALL3D model.

According to the Shao scheme, the emission rate depends on the particle grain size distribution of the deposit. We assume a grain size distribution uniform throughout the model domain discretized along 14 classes. Each particle class is characterized by its particle size $d$, density $\rho$, and shape. We used a log-normal distribution ranging from $\phi=0$ to $\phi=8\left(\phi=-\log _{2}(d)\right.$, with $d$ in $\left.\mathrm{mm}\right)$. The parameters of the distribution, obtained from field measurements, are mean, $\bar{\phi}=3 \phi$, and standard deviation, $\sigma_{\phi}=1.5 \phi$ (J. G. Viramonte, personal communication, 2015). The density of particles varies linearly with $\phi$ between 1.2 and $2.2 \mathrm{~g} \mathrm{~cm}^{-3}$ and a constant sphericity $\Phi=0.9$ is assumed. Only the finest particles $(d<60 \mu \mathrm{m})$ are injected into the atmosphere (see Sect. 3.2.1 for further details). However, the saltation flow, $Q$, must be estimated for each particle class since the full distribution $(\phi=0-8)$ is required in Eq. (5) to calculate the vertical flux of the finest particles.

The WRF output fields required for the emission scheme are friction velocity and soil moisture for the upper soil model layer (at $10 \mathrm{~cm}$ depth). Figure 8 shows that the friction velocity for the innermost WRF domain $(2 \mathrm{~km})$ is strongly correlated with the orographic features of the region, with the largest friction velocities occurring in steep terrain (compare Fig. 8 with Fig. 7).

Figure 10 shows the grid emitted mass throughout the $54 \mathrm{~h}$ simulation, computed from the $2 \mathrm{~km}$ WRF fields. The dust emission occurs predominantly in the north of the Fiambala Basin due to the strong downslope winds of the region.

Figure 11 shows the time series of the dust emission rate (emission flux spatially integrated) for the 2,6 , and $18 \mathrm{~km}$ WRF fields. According to the emission rate driven by the $2 \mathrm{~km} u_{*}$, the dust emission occurred on 13 June during the presence of the zonda wind episode. The model predicts a maximum emission at around 15:00 UTC. The dust emission fluxes are very sensitive to horizontal resolution: the source strength computed with the 6 and $18 \mathrm{~km}$ meteorological fields decreases significantly. This result is a direct consequence of the dependence of friction velocity on spatial resolution. In these cases, a reduced duration of the dust outbreak is predicted by the model, with the maxima remaining at 15:00 UTC. The total mass emitted for the entire study period for each domain were $1.7 \times 10^{9} \mathrm{~kg}(2 \mathrm{~km}), 0.48 \times 10^{9} \mathrm{~kg}$ $(6 \mathrm{~km})$, and $0.17 \times 10^{9} \mathrm{~kg}(18 \mathrm{~km})$.

The gray-shaded area in Fig. 11 represents the time window with satellite detection of dust around the source area. The dust cloud is detected by the SEVIRI RGB dust product from 14:00 UTC. According to simulations, the emission occurred before satellite detection.

It should be noted that errors can exist due to the uncertainty in the area of potential sources of dust. Since the simulations depend strongly on the availability of local dust

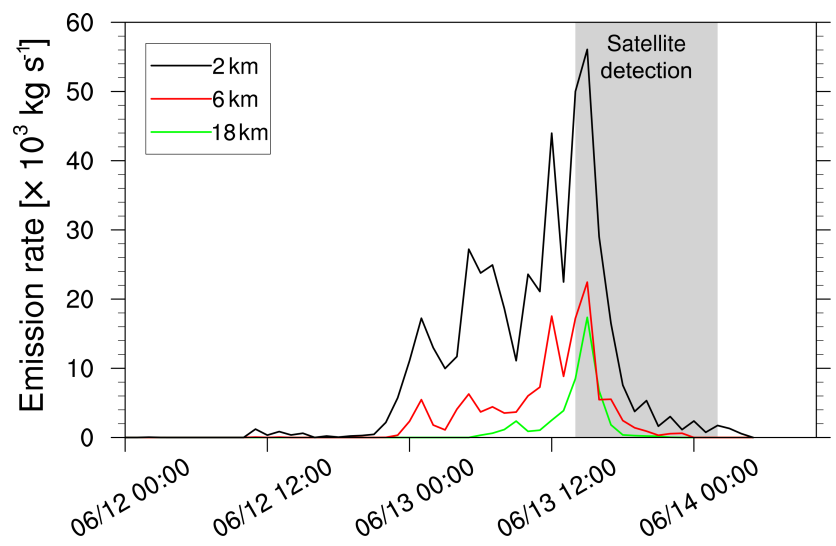

Figure 11. Time series for the emission rate (spatially integrated) driven by meteorological inputs at different horizontal resolutions $(2,6$, and $18 \mathrm{~km})$. The dust flux is remarkable sensitive to friction velocity resolution. The gray-shaded area represents the time window with satellite detection of airborne dust. According to simulations, the emission occurred before satellite detection.

sources, a complete dataset of regional soil properties is required for improvement of the results. Additionally, there are errors associated with the WRF-ARW output fields, because the scales involved in the mesoscale model are not representative of the spatial scales pertinent to the dust emission processes. In fact, the WRF surface layer scheme is based on the Monin-Obukhov similarity theory (Monin and Obukhov, 1954). According to this theory, the calculation of $u_{*}$ depends on the roughness length, $z_{0}$. As noted by Darmenova et al. (2009), roughness lengths relevant to the aeolian processes, with typical values for erodible surfaces ranging from $10^{-3}$ to $1 \mathrm{~cm}$, may differ significantly from the mesoscale model roughness lengths. In this case, an alternative approach to compute the friction velocity would be advisable. For example, Darmenova et al. (2009) suggested recalculating $u_{*}$ using an external dataset of $z_{0}$ instead of the roughness length from the WRF model. Furthermore, the $10 \mathrm{~cm}$ depth soil moisture appears to be unrepresentative of the soil surface conditions involved in the dust emission processes.

\subsection{Short-range transport}

In this section, the FALL3D results corresponding to the short-range simulations $\left(0.01^{\circ}\right.$ domain $)$ are analyzed in order to study the spatial distribution of dust concentration over the Fiambalá Basin. Figure 12 shows a meridional cross section along $P$ longitude $\left(67.7^{\circ} \mathrm{W}\right)$ at different times.

At 11:00 UTC on 13 June, mineral dust is emitted from the northern part of the Fiambalá Basin, between 27.2 and $27.1^{\circ} \mathrm{S}$ (Fig. 12a). The dust emission region can be recognized by the particle column mass peak (red solid line) and the large values of dust concentration. Aerosol particles remain confined to near-ground layers north of latitude $27.5^{\circ} \mathrm{S}$ and tend to be removed from the atmosphere by settling. An 
(a)

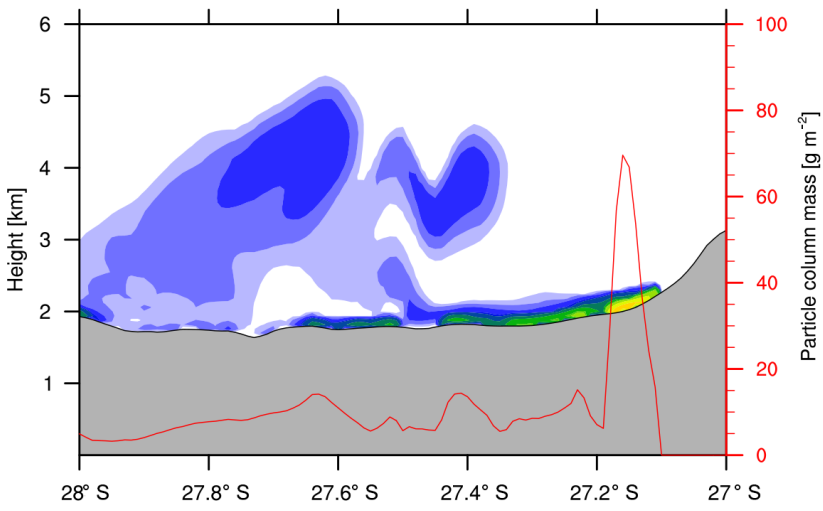

(b)

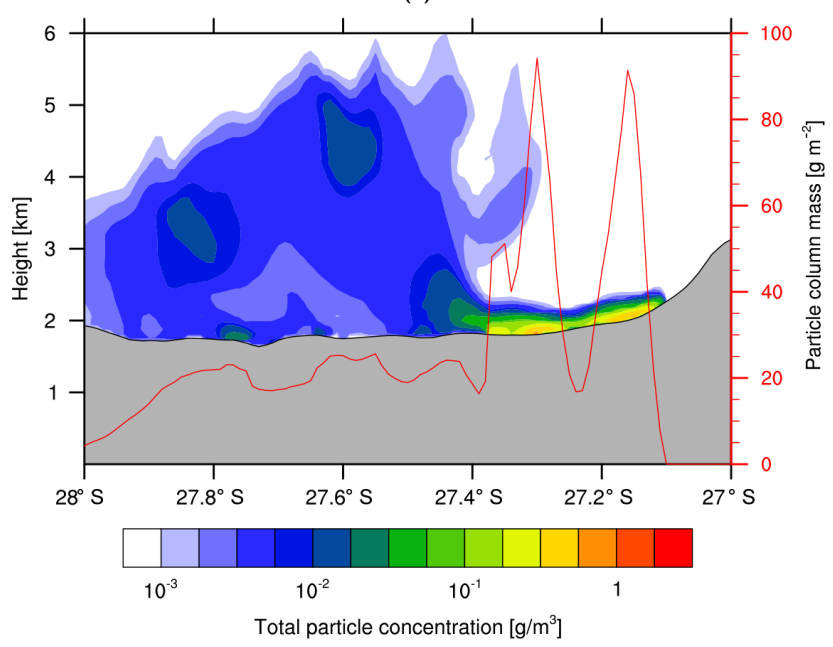

Figure 12. Spatial distribution of the modeled dust concentration over the Fiambalá Basin. Meridional cross section along longitude $67.7^{\circ} \mathrm{W}$. The red solid line represents the particle column mass profile. The emission sources are centered around the peaks of column mass. (a) 13 June at 11:00 UTC. (b) 13 June at 16:00 UTC.

abrupt reduction of the near-ground concentration of dust occurs south of latitude $27.5^{\circ} \mathrm{S}$, where dust aerosols are injected into greater heights.

At 16:00 UTC on 13 June a second peak in the particle column mass profile of Fig. 12b denotes the emergence of new emission sources between 27.4 and $27.3^{\circ} \mathrm{S}$. In this case, it is observed a similar situation as that in Fig. 12a: in the northern part of the Fiambalá Basin dust particles are distributed over the lowest atmospheric layer, whereas in the central and southern regions the vertical distribution of dust aerosols extends up to $5-6 \mathrm{~km}$.

The spatial distribution pattern of the dust concentration can be explained from Fig. 13, where a meridional cross section at 16:00 UTC of vertical wind velocity is shown. A descending air mass dominates the northern region of the Fiambalá Basin, leading to an accumulation of particles in the lower layers and creating favorable conditions for dust emission due to the strong downslope winds in surface. However,

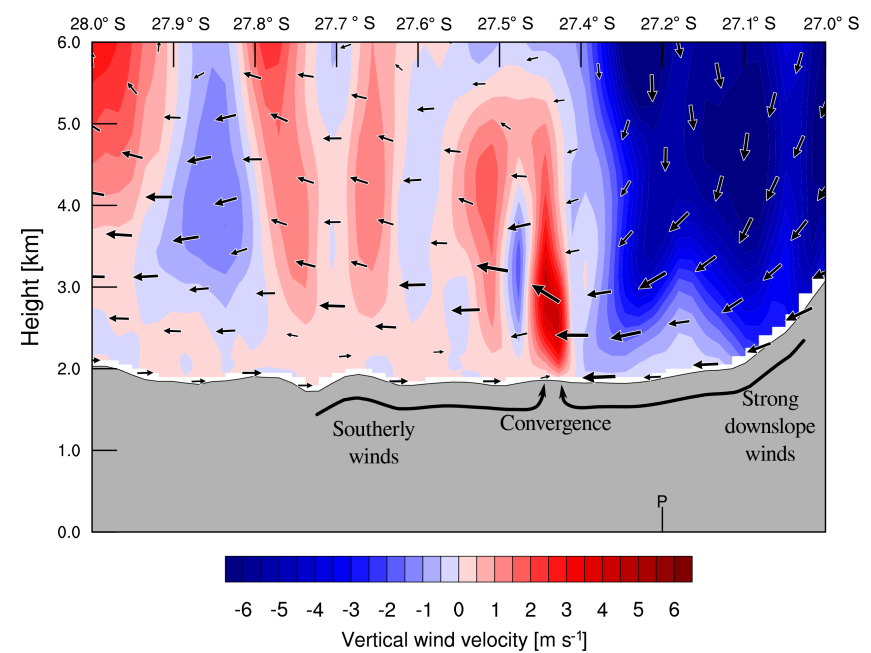

Figure 13. Meridional cross section of vertical velocity on 13 June at 16:00 UTC according to $2 \mathrm{~km}$ WRF-ARW output. As a result of orographic effects, intense ascending airflows driven by horizontal convergence occurred in Fiambalá Basin, between $27.5^{\circ} \mathrm{S}$ and $27.4^{\circ} \mathrm{S}$ (longitude: $\sim 67.7^{\circ} \mathrm{W}$ ).

Fig. 13 shows the presence of ascending airflows driven by horizontal convergence between 27.5 and $27.4^{\circ} \mathrm{S}$ (see also Fig. 8) with vertical velocities greater than $6 \mathrm{~m} \mathrm{~s}^{-1}$. Dust aerosols are injected to greater heights in this region according to the dust vertical distribution shown in Fig. 12b.

This result suggests that ascending airflow driven by horizontal convergence in the Fiambalá Basin might have been an important dust injection mechanism. In order to quantify the dust injection height, we define the cloud top height at a specific location as the maximum height at which a concentration of $1 \mathrm{mg} \mathrm{m}^{-3}$ is attained (i.e., the highest contour in Fig. 12). Figure 14 shows the time series for the cloud top height over the Fiambalá Basin, i.e., the cloud height averaged over the FALL3D fine domain $\left(28-27^{\circ} \mathrm{S}\right.$ and $68-67.3^{\circ} \mathrm{W}$ ). Two mechanisms promote the dust injection into the atmosphere from 14:00 UTC: (a) the ascending air mass intensifies and (b) the emission occurs close to the surface convergence. The latter mechanism is clearly visible in Fig. 12b. The southernmost peak of the particle column mass profile denotes a set of dust sources supplying particles to the ascending air airflow located at $\sim 27.4^{\circ} \mathrm{S}$. As a consequence, a significant amount of mass can be uplifted and the background column mass over the Fiambalá Basin increases.

According to the numerical simulations, the maximum height is reached at 16:00 UTC and a steep increase of the cloud top occurs between 14:00 and 15:00 UTC, when dust satellite detection begins (gray-shaded area). The elevated height of the dust cloud and the increased column mass background appear to be the conditions that allowed the satellite detection of dust over the central and southern regions of the Fiambalá Basin. Satellite detection of mineral dust becomes evident between $\sim 27.5$ and $\sim 27.9^{\circ} \mathrm{S}$ in the SEVIRI im- 


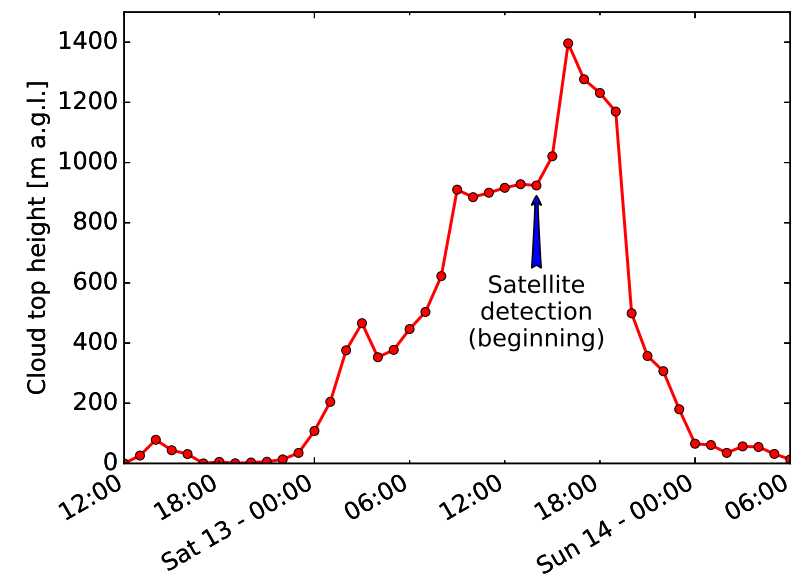

Figure 14. Time series for the cloud top height (defined as the maximum height at which a concentration of $1 \mathrm{mg} \mathrm{m}^{-3}$ is attained) over the Fiambalá Basin. Data are averaged over the FALL3D fine domain $\left(28-27^{\circ} \mathrm{S}\right.$ and $\left.68-67.3^{\circ} \mathrm{W}\right)$. A significant increase in cloud height occurs between 14:00 and 15:00 UTC, coinciding with the onset of dust detection by satellite (blue arrow).

age at 16:00 UTC on 13 June, in agreement with the region where the modeled dust cloud reaches its maximum height in Fig. 12b. However, the low cloud heights prevent satellite detection in the north of the Fiambalá Basin, where the emission occurs and the model predicts the highest concentration values.

\subsection{Long-range transport}

Numerical simulations of long-range transport were performed to model dust cloud spreading over northern Argentina. The results of FALL3D $\left(0.1^{\circ}\right.$ domain $)$ are compared with satellite imagery in this section.

Both the meteorological and the dispersal models in our modeling strategy use terrain-following coordinates. As a consequence, simulations over the extremely complex orography of the region represent a challenge for the modeling system. For example, it is recognized that errors in computing the horizontal pressure-gradient force in terrainfollowing coordinates may arise in regions of steep terrain (Janjic, 1977; Klemp et al., 2003). The WRF-ARW equations are formulated using a terrain-following hydrostaticpressure vertical coordinate (Skamarock et al., 2008). Instead, FALL3D model uses a simple terrain-following coordinate system where the horizontal coordinates remain unchanged: $x=X, y=Y, z \rightarrow Z$, where $Z=z-h(x, y)$, with $h(x, y)$ denoting the topographic elevation (Costa et al., 2006), $(x, y, z)$ the coordinates in an ordinary Cartesian system, and $(X, Y, Z)$ the coordinates in the FALL3D system.

We conducted the simulations using two numerical methods to compute the advection terms of the advectiondiffusion-sedimentation equation from the FALL3D

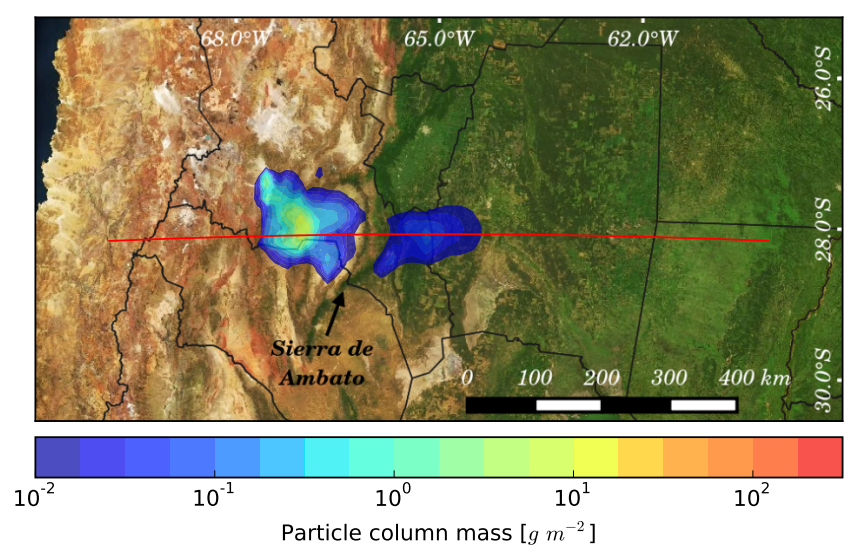

Figure 15. FALL3D output column mass on 13 June at 23:00 UTC using the default configuration. The transport of dust aerosols is partly blocked by the orographic barrier Sierra de Ambato.

model (Costa et al., 2006):

$U \frac{\partial C}{\partial x}+V \frac{\partial C}{\partial y}+W \frac{\partial C}{\partial z}$

where $U, V$, and $W$ are the wind components. In the simpler method (default configuration), the terms of Eq. (9) are computed using the wind components provided by the WRF model, and the gradients are computed using points on the same model level. In the alternative method, the vertical wind velocity is replaced by

$W \rightarrow W-\left(U \frac{\partial h}{\partial x}+V \frac{\partial h}{\partial y}\right)$

to more accurately compute the horizontal advection in sloped coordinates. Using this approach the Eq. (9) remains invariant under the transformation of the FALL3D terrainfollowing coordinate system.

The modeled particle column mass on 13 June at 23:00 UTC using the default method is shown in Fig. 15. The dust aerosols remain close to the source region throughout the simulation. In this case, the concentration diminishes steeply through the Sierra de Ambato orographic barrier (see Fig. 1). Figure 16 shows the modeled concentration on 13 June at 23:00 UTC in a west-east cross section along the red line shown in Fig. 15. Numerical errors in the advection calculation can lead to a poor performance in sloping terrain using the FALL3D default configuration. Figure 16a shows that the particles tend to remain in the same model level and the dust aerosols are partly "blocked" by the orographic barrier. With the method based on the Eq. (10), the dust cloud is transported eastward over longer distances downwind the orographic barrier (Fig. 16b), more in agreement with the satellite imagery (see Fig. 3). The results show that the correction based on Eq. (10) improves the performance of FALL3D in sloped terrain. Therefore, it is advisable to use this configuration by default. 
(a)

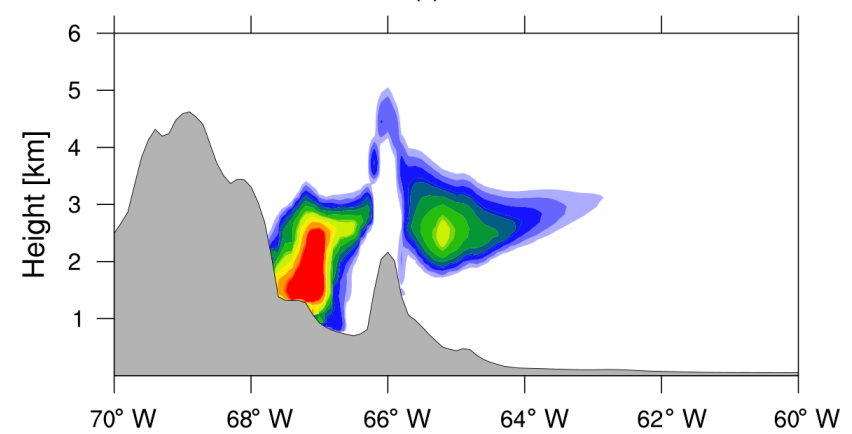

(b)

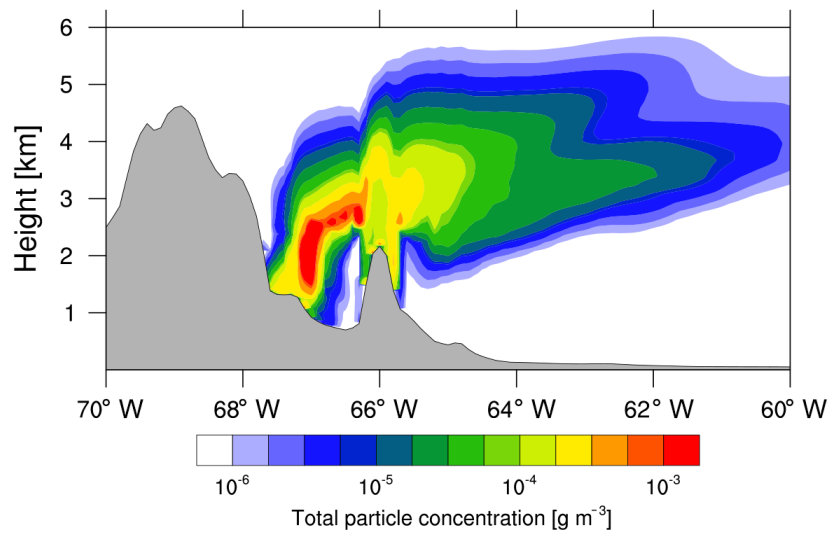

Figure 16. Modeled concentration on 13 June at 23:00 UTC. Westeast cross section along the red line in Fig. 15 (latitude: $28.2^{\circ} \mathrm{S}$ ). Two numerical schemes are tested. (a) FALL3D default configuration. (b) Alternative configuration using a numerical scheme to more accurately compute the horizontal advection in abrupt terrains (see Eq. 10).

The sequence of particle column mass modeled using the vertical velocity correction given by Eq. (10) is shown in Fig. 17. Initially, dust raised into the atmosphere is carried southeastwards by the orographic winds. Subsequently, the uplifted dust reaches greater heights and the dust cloud is advected eastwards by the mid-level westerly winds. Comparisons among model output and satellite imagery reveal that the modeled dust cloud is further north (see Fig. 3). In conclusion, these results highlight the difficulty of modeling the transport of aerosols in the extremely complex terrain of the region.

\section{Conclusions}

On 13 June 2015, the Buenos Aires VAAC was informed about a suspected volcanic eruption in the proximity of the Ojos del Salado-San Buenaventura volcanic lineament. A volcanic ash cloud was detected by the infrared channels of the SEVIRI instrument, carried on board MSG satellites. This event triggered a thorough interdisciplinary investigation. As a result, Collini et al. (2015) concluded that the phe-
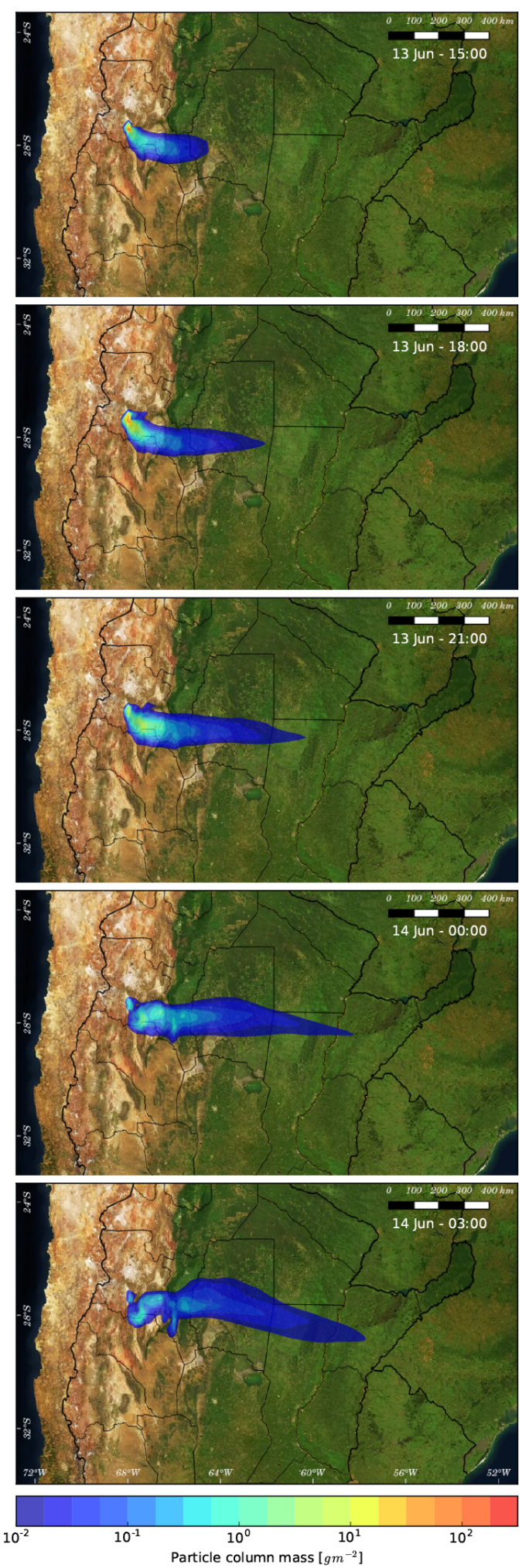

Figure 17. Column mass from FALL3D simulations using the alternative configuration. Vertical wind velocity was recalculated to reduce errors in sloping terrain. Simulation at 15:00, 18:00, 21:00 (13 June), 00:00, and 03:00 UTC (14 June). 
nomenon was caused by remobilization of ancient pyroclastic deposits from the Bolsón de Fiambalá (Fiambalá Basin).

In this work, we performed numerical simulations of windblown dust using the WRF-ARW/FALL3D modeling system. A successful description of the emission processes and the spatiotemporal distribution of dust concentration represents a challenge for the modeling system due to the extremely complex orography of the region, with variations in terrain height of about $5000 \mathrm{~m}$ over horizontal distances of the order of $100 \mathrm{~km}$.

The modeling strategy followed three consecutive steps: (i) meteorological model run, (ii) calculation of dust emission rates, and (iii) dispersal model run.

i. The WRF-ARW meteorological model was run using three two-way nested domains. The meteorological fields were downscaled to a spatial resolution of $2 \mathrm{~km}$ to resolve the complex orography of the study region. The results of the numerical simulations are compatible with the presence of a zonda wind throughout 13 June: formation of mountains waves, a very dry air column on the lee side of the mountain range, and strong surface winds.

ii. Emission flux: the WRF output fields are required by the FALL3D model to compute the emission rates and the subsequent transport of mineral dust. The dust emission rate was computed using the parametrizations of the Shao scheme implemented in FALL3D with minor modifications. According to the results, during the dust outbreak strong downslope winds affected the northern part of the Fiambalá Basin, creating favorable conditions for the uplift of mineral dust. We showed that the simulated emission rates are very sensitive to horizontal resolution of the meteorological fields. Specifically, the total dust emitted for the entire study period were 1.7, 0.48 , and $0.17 \times 10^{9} \mathrm{~kg}$ for the spatial resolutions of 2 , 6 , and $18 \mathrm{~km}$, respectively.

iii. Dispersal model run: in order to study the spatial distribution of the modeled dust concentration over the Fiambalá Basin, we performed numerical simulations of short-range transport using the FALL3D model. Most of the particles are concentrated in the northern regions, where the emission sources are located. As a consequence of the intensive descending airflows, with downward velocities of over $7 \mathrm{~m} \mathrm{~s}^{-1}$, the particles are distributed in a thin near-ground layer in these regions. Conversely, dust aerosols were injected up to $5-6 \mathrm{~km}$ in the central and southern regions of the Fiambalá Basin according to simulations.

Long-range transport numerical simulations were also performed to model dust cloud spreading over northern Argentina and the simulated vertical particle column mass was compared with the MSG-SEVIRI retrieval product. We tested two numerical schemes: difficulties arose to simulate transport through orographic barriers with the default configuration of the FALL3D model. An alternative configuration, using a numerical scheme to more accurately compute the horizontal advection in abrupt terrains, substantially improved the model performance.

Data availability. ERA-Interim reanalysis data (model levels, pressure levels, and surface) are available from http://apps.ecmwf.int/ datasets/data/interim-full-daily/.

WRF-ARW was run using static data (land use and topography) from the US Geological Survey (USGS) available from http://www2.mmm.ucar.edu/wrf/users/download/get_sources_ wps_geog.html.

Data of temperature, dew point temperature, and surface wind speed at Mina Alumbrera Airport, Catamarca $\left(27^{\circ} 4^{\prime} 36^{\prime \prime} \mathrm{S}-\right.$ $66^{\circ} 35^{\prime} 37^{\prime \prime} \mathrm{W}$ ), were provided by the National Weather Service of Argentina (available upon request: smn@smn.gob.ar).

The images from SEVIRI were provided by the National Institute for Space Research (INPE), Center for Weather Forecast and Climate Studies (CPTEC), Satellite Division and Environmental Systems (DSA), Brazil (http://www.cptec.inpe.br/).

Numerical simulations were performed using the WRFARW model, available from http://www2.mmm.ucar.edu/wrf/users/ downloads.html, and the FALL3D model, available from http:// bsccase 02.bsc.es/projects/fall3d/.

\section{The Supplement related to this article is available online at https://doi.org/10.5194/acp-17-6759-2017-supplement.}

Competing interests. The authors declare that they have no conflict of interest.

Acknowledgements. Leonardo A. Mingari thanks CONICET for their PhD fellowship. The WRF-ARW/FALL3D modeling system ran in a server installed at the SMN with funds from the Argentinean project PIDDEF 41/10: "Pronóstico del tiempo para estudios de vulnerabilidad e impacto socioeconómico". The images from SEVIRI were provided by Diego Souza from National Institute for Space Research (INPE), Center for Weather Forecast and Climate Studies (CPTEC), Satellite Division and Environmental Systems (DSA), Brazil. We thank the Servicio Meteorologico Nacional (Argentina) for providing the meteorological data from the weather station at Catamarca Airport. The authors would like to thank Miriam Andrioli of the National Meteorological Service of Argentina for providing information about the study episode. We thank Julia Paegle for her valuable comments on the manuscript. Finally, we would like to thank Larry Mastin and Frances Beckett for their thoughtful reviews of the manuscript.

Edited by: Matthias Tesche

Reviewed by: Larry Mastin and Frances Beckett 


\section{References}

Allende, D. G., Mulena, G. C., Puliafito, S. E., Lakkis, S. G., Cremades, P. G., and Castro, F. H.: A first approach on modeling windblown dust in Zonda wind events, in: Proceedings of the XI Argentine Congress on Meteorology (CONGREMET XI), Mendoza, Argentina, 28 May-1 June 2012.

Álvarez, O., Gimenez, M., Folguera, A., Spagnotto, S., Bustos, E., Baez, W., and Braitenberg, C.: New evidence about the subduction of the Copiapó ridge beneath South America, and its connection with the Chilean-Pampean flat slab, tracked by satellite GOCE and EGM2008 models, J. Geodyn., 91, 65-88, 2015.

Arnosio, M., Becchio, R., Viramonte, J. G., Groppelli, G., Norini, G., and Corazzato, C.: Geología del Complejo Volcánico Cerro Blanco ( $\left.26^{\circ} 45^{\prime} \mathrm{LS}-67^{\circ} 45^{\prime} \mathrm{LO}\right)$, Puna Austral, in: Proceedings of the XVI Argentine Congress on Geology, La Plata, Argentina, 20-23 September 2005, 1, 851-858, 2005.

Arnosio, M., Becchio, R., Viramonte, J. G., de Silva, S., and Viramonte, J.: Geocronología e isotopía del complejo volcánico Cerro Blanco: Un sistema de calderas cuaternario (73-12 ka) en los Andes Centrales del Sur, in: Proceedings of the XVII Argentine Congress on Geology, Jujuy, Argentina, 7-10 October 2008, 1, 177-178, 2008.

Báez, W., Arnosio, M., Chiodi, A., Ortiz-Yañes, A., Viramonte, J. G., Bustos, E., Giordano, G., and López, J. F.: Estratigrafía y evolución del Complejo Volcánico Cerro Blanco, Puna Austral, Argentina, Rev. Mex. Cienc. Geol., 32, 29-49, 2015.

Bagnold, R. A.: The Physics of Blown Sand and Desert Dunes, Methuen, London, 1941.

Baker, P., González-Ferrán, O., and Rex, D.: Geology and geochemistry of the Ojos del Salado volcanic region, Chile, J. Geol. Soc. London, 144, 85-96, 1987.

Banks, J. R. and Brindley, H. E.: Evaluation of MSG-SEVIRI mineral dust retrieval products over North Africa and the Middle East, Remote Sens. Environ., 128, 58-73, 2013.

Banks, R. F., Tiana-Alsina, J., Baldasano, J. M., Rocadenbosch, F., Papayannis, A., Solomos, S., and Tzanis, C. G.: Sensitivity of boundary-layer variables to PBL schemes in the WRF model based on surface meteorological observations, lidar, and radiosondes during the HygrA-CD campaign, 176-177, 185201, 2016.

Benedetti, A., Baldasano, J. M., Basart, S., Benincasa, F., Boucher, O., Brooks, M. E., Chen, J.-P., Colarco, P. R., Gong, S., Huneeus, N., Jones, L., Lu, S., Menut, L., Morcrette, J.-J., Mulcahy, J., Nickovic, S., Pérez García-Pando, C., Reid, J. S., Sekiyama, T. T., Tanaka, T. Y., Terradellas, E., Westphal, D. L., Zhang, X.Y., and Zhou, C.-H.: Operational Dust Prediction, in: Mineral Dust: A Key Player in the Earth System, edited by: Knippertz, P. and Stuut, J.-B. W., Springer Netherlands, 223-265, 2014.

Brinkmann, W. A.: Strong downslope winds at Boulder, Colorado, Mon. Weather Rev., 102, 592-602, 1974.

Bustos, E., Arnosio, J. M., and Norini, G.: Análisis morfológico del complejo volcánico La Hoyada Puna Austral mediante la aplicación de Modelos de Elevación Digital, Revista de la Asociación Geológica Argentina, 72, 279-291, 2015.

Byun, D. and Schere, K. L.: Review of the governing equations, computational algorithms, and other components of the Models3 Community Multiscale Air Quality (CMAQ) modeling system, Appl. Mech. Rev., 59, 51-77, 2006.
Carrapa, B., Strecker, M., and Sobel, E.: Cenozoic orogenic growth in the Central Andes: Evidence from sedimentary rock provenance and apatite fission track thermochronology in the Fiambalá Basin, southernmost Puna Plateau margin (NW Argentina), Earth Planet. Sc. Lett., 247, 82-100, 2006.

Chen, F. and Dudhia, J.: Coupling an advanced land surfacehydrology model with the Penn State-NCAR MM5 modeling system. Part I: Model implementation and sensitivity, Mon. Weather Rev., 129, 569-585, 2001.

Collini, E., Osores, M. S., Folch, A., Viramonte, J. G., Villarosa, G., and Salmuni, G.: Volcanic ash forecast during the June 2011 Cordón Caulle eruption, Nat. Hazards, 66, 389-412, 2013.

Collini, E., Mingari, L., Reckziegel, F., Bustos, E., Baez, W., Andrioli, M., Folch, A., Alexander, P., and Viramonte, J.: Satellite images uncertainty: eruption or resuspension? The importance of the multidisciplinary approach. The case of June 13th, 2015 Ojos del Salado false volcanic eruption, 7th WMO International Workshop on Volcanic Ash (IVAW-7), Anchorage, Alaska, 1923 October 2015.

Costa, A., Macedonio, G., and Folch, A.: A three-dimensional Eulerian model for transport and deposition of volcanic ashes, Earth Planet. Sc. Lett., 241, 634-647, 2006.

Darmenov, A. S.: Developing and testing a coupled regional modeling system for establishing an integrated modeling and observational framework for dust aerosol, $\mathrm{PhD}$ thesis, Georgia Institute of Technology, Atlanta, USA, 2009.

Darmenova, K., Sokolik, I. N., Shao, Y., Marticorena, B., and Bergametti, G.: Development of a physically based dust emission module within the Weather Research and Forecasting (WRF) model: Assessment of dust emission parameterizations and input parameters for source regions in Central and East Asia, J. Geophys. Res., 114, D14201, https://doi.org/10.1029/2008JD011236, 2009.

Dee, D., Uppala, S., Simmons, A., Berrisford, P., Poli, P., Kobayashi, S., Andrae, U., Balmaseda, M., Balsamo, G., Bauer, P., Bechtold, P., Beljaars, A. C. M., van de Berg, L., Bidlot, J., Bormann, N., Delsol, C., Dragani, R., Fuentes, M., Geer, A. J., Haimberger, L., Healy, S. B., Hersbach, H., Hólm, E. V., Isaksen, L., Kållberg, P., Köhler, M., Matricardi, M., McNally, A. P., Monge-Sanz, B. M., Morcrette, J.-J., Park, B.-K., Peubey, C., de Rosnay, P., Tavolato, C., Thépaut, J.-N., and Vitart, F.: The ERA-Interim reanalysis: Configuration and performance of the data assimilation system, Q. J. Roy. Meteor. Soc., 137, 553-597, 2011.

Elissondo, M., Baumann, V., Bonadonna, C., Pistolesi, M., Cioni, R., Bertagnini, A., Biass, S., Herrero, J.-C., and Gonzalez, R.: Chronology and impact of the 2011 Cordón Caulle eruption, Chile, Nat. Hazards Earth Syst. Sci., 16, 675-704, https://doi.org/10.5194/nhess-16-675-2016, 2016.

Fécan, F., Marticorena, B., and Bergametti, G.: Parametrization of the increase of the aeolian erosion threshold wind friction velocity due to soil moisture for arid and semi-arid areas, Ann. Geophys., 17, 149-157, https://doi.org/10.1007/s00585-999-0149-7, 1999.

Fernandez Turiel, J. L., Saavedra, J., Perez Torrado, F. J., Rodriguez Gonzalez, A., Carracedo, J. C., Lobo, A., Rejas, M., Gallardo, J. F., Osterrieth, M., Carrizo, J., Esteban, G., Martinez, L. D., Gil, R. A., Ratto, N., and Baez, W.: The ash deposits of the 4200 BP Cerro Blanco eruption: the largest Holocene eruption 
of the Central Andes, EGU General Assembly, Vienna, Austria, 12-17 April 2015, EGU2015-3392, 2015.

Fleagle, R. G.: A theory of air drainage, J. Meteorol., 7, 227-232, 1950.

Folch, A., Costa, A., and Macedonio, G.: FALL3D: A computational model for transport and deposition of volcanic ash, Comput. Geosci., 35, 1334-1342, 2009.

Folch, A., Mingari, L., Osores, M. S., and Collini, E.: Modeling volcanic ash resuspension - application to the 14-18 October 2011 outbreak episode in central Patagonia, Argentina, Nat. Hazards Earth Syst. Sci., 14, 119-133, https://doi.org/10.5194/nhess-14119-2014, 2014.

Gaiero, D. M.: Dust provenance in Antarctic ice during glacial periods: From where in southern South America?, Geophys. Res. Lett., 34, https://doi.org/10.1029/2007GL030520, L17707, 2007.

Gaiero, D. M., Simonella, L., Gassó, S., Gili, S., Stein, A. F., Sosa, P., Becchio, R., Arce, J., and Marelli, H.: Ground/satellite observations and atmospheric modeling of dust storms originating in the high Puna-Altiplano deserts (South America): Implications for the interpretation of paleo-climatic archives, J. Geophys. Res., 118, 3817-3831, 2013.

Ganser, G. H.: A rational approach to drag prediction of spherical and nonspherical particles, Powder Technol., 77, 143-152, 1993.

Garreaud, R. D.: The Andes climate and weather, Adv. Geosci., 22, 3-11, https://doi.org/10.5194/adgeo-22-3-2009, 2009.

Greeley, R. and Iversen, J. D.: Wind as a geological process: On Earth, Mars, Venus and Titan, Vol. 4, Cambridge University Press, Cambridge, UK, 1985.

Hadley, D., Hufford, G. L., and Simpson, J. J.: Resuspension of relic volcanic ash and dust from Katmai: still an aviation hazard, Weather Forecast., 19, 829-840, 2004.

Jacobson, M. Z.: Fundamentals of atmospheric modeling, 2nd Edn., Cambridge University Press, Cambridge, UK, 2005.

Janjic, Z. I.: Pressure gradient force and advection scheme used for forecasting with steep and small scale topography, Beiträge zur Physik der Atmosphäre, 50, 186-199, 1977.

Janjic, Z. I.: The step-mountain eta coordinate model: Further developments of the convection, viscous sublayer, and turbulence closure schemes, Mon. Weather Rev., 122, 927-945, 1994.

Janjic, Z. I.: The surface layer parameterization in the NCEP Eta Model, in: Proceedings of the 11th Conference on Numerical Weather Prediction, Norfolk, Virginia, 354-355, 1996.

Johnson, M. S., Meskhidze, N., Solmon, F., Gassó, S., Chuang, P. Y., Gaiero, D. M., Yantosca, R. M., Wu, S., Wang, Y., and Carouge, C.: Modeling dust and soluble iron deposition to the South Atlantic Ocean, J. Geophys. Res., 115, D15202, https://doi.org/10.1029/2009JD013311, 2010.

Kay, S. M. and Coira, B. L.: Shallowing and steepening subduction zones, continental lithospheric loss, magmatism, and crustal flow under the Central Andean Altiplano-Puna Plateau, Geol. Soc. Am. Mem., 204, 229-259, 2009.

Kishcha, P., Rieger, D., Metzger, J., Starobinets, B., Bangert, M., Vogel, H., Schättler, U., Corsmeier, U., Alpert, P., and Vogel, B.: Modelling of a strong dust event in the complex terrain of the Dead Sea valley during the passage of a gust front, Tellus B, 68, 29751, https://doi.org/10.3402/tellusb.v68.29751, 2016.

Klemp, J. B. and Lilly, D. R.: The dynamics of wave-induced downslope winds, J. Atmos. Sci., 32, 320-339, 1975.
Klemp, J. B., Skamarock, W. C., and Fuhrer, O.: Numerical consistency of metric terms in terrain-following coordinates, Mon. Weather Rev., 131, 1229-1239, 2003.

Knippertz, P. and Stuut, W. J.-B. (Eds.): Mineral Dust: A Key Player in the Earth System, Springer Science, 2014.

Kok, J. F., Parteli, E. J., Michaels, T. I., and Karam, D. B.: The physics of wind-blown sand and dust, Rep. Prog. Phys., 75, 106901, https://doi.org/10.1088/0034-4885/75/10/106901, 2012.

Kurgansky, M. V., Montecinos, A., Villagran, V., and Metzger, S. M.: Micrometeorological conditions for dust-devil occurrence in the Atacama Desert, Bound.-Lay. Meteorol., 138, 285-298, 2011.

Lamb, P. J.: Nor'wester's potential föhn influence on Canterbury Plains'(New Zealand) surface heat exchanges, New Zeal. J. Agr. Res., 17, 349-353, 1974.

Leadbetter, S. J., Hort, M. C., von Löwis, S., Weber, K., and Witham, C. S.: Modeling the resuspension of ash deposited during the eruption of Eyjafjallajökull in spring 2010, J. Geophys. Res., 117, D00U10, https://doi.org/10.1029/2011JD016802, 2012.

Lindesay, J. A. and Tyson, P. D.: Thermo-topographically induced boundary layer oscillations over the central Namib, southern Africa, Int. J. Climatol., 10, 63-77, 1990.

Liu, E. J., Cashman, K. V., Beckett, F. M., Witham, C. S., Leadbetter, S. J., Hort, M. C., and Guðmundsson, S.: Ash mists and brown snow: Remobilization of volcanic ash from recent Icelandic eruptions, J. Geophys. Res., 119, 9463-9480, https://doi.org/10.1002/2014JD021598, 2014.

Liu, M. and Westphal, D. L.: A study of the sensitivity of simulated mineral dust production to model resolution, J. Geophys. Res. 106, 18099-18112, 2001.

Marticorena, B. and Bergametti, G.: Modeling the atmospheric dust cycle: 1 . Design of a soil-derived dust emission scheme, J. Geophys. Res., 100, 16415-16430, 1995.

Marticorena, B., Bergametti, G., Aumont, B., Callot, Y., N’Doumé, C., and Legrand, M.: Modeling the atmospheric dust cycle: 2. Simulation of Saharan dust sources, J. Geophys. Res., 102, 4387 4404, 1997.

McPherson, H. M.: Climate and tectonic controls on sedimentation and deformation in the Fiambalá Basin of the southern Puna Plateau, Northwest Argentina, PhD thesis, The Ohio State University, Ohio, USA, 2008.

Middleton, N.: The geography of dust storms, PhD thesis, University of Oxford, Oxford, UK, 1986.

Middleton, N. J. and Goudie, A. S.: Saharan dust: sources and trajectories, T. I. Brit. Geogr., 26, 165-181, https://doi.org/10.1111/1475-5661.00013, 2001.

Monin, A. S. and Obukhov, A. M.: Basic laws of turbulent mixing in the surface layer of the atmosphere, Contrib. Geophys. Inst Acad. Sci. USSR, 151, 163-187, 1954.

Montero Lopez, M. C., Hongn, F., Brod, J. A., Seggiaro, R., Marrett, R., and Sudo, M.: Magmatismo ácido del mioceno superiorcuaternario en el área de Cerro Blanco-La Hoyada, Puna Austral, Revista de la Asociación Geológica Argentina, 67, 329-348, 2010a.

Montero Lopez, M. C., Hongn, F., Seggiaro, R., Brod, J. A., and Marrett, R.: Estratigrafía y geoquímica del volcanismo de composición intermedia (Mioceno superior-Plioceno) en el extremo 
oriental de la Cordillera de San Buenaventura (Puna Austral), Revista de la Asociación Geológica Argentina, 67, 112-129, $2010 \mathrm{~b}$.

Montero Lopez, M. C., Hongn, F. D., Strecker, M. R., Marrett, R., Seggiaro, R., and Sudo, M.: Late Miocene-early Pliocene onset of N-S extension along the southern margin of the central Andean Puna Plateau: Evidence from magmatic, geochronological and structural observations, Tectonophysics, 494, 48-63, 2010c.

Mpodozis, C., Kay, S. M., Gardeweg, M., and Coira, B.: Geología de la región de Ojos del Salado (Andes centrales, $27^{\circ} \mathrm{S}$ ): implicancias de la migración hacia el este del frente volcánico Cenozoico Superior, in: Proceedings of the XIII Argentine Congress on Geology, Buenos Aires, Argentina, 13-18 October 1996, 3, 539-548, 1996.

Nickovic, S., Kallos, G., Papadopoulos, A., and Kakaliagou, O.: A model for prediction of desert dust cycle in the atmosphere, J. Geophys. Res., 106, 18113-18129, 2001.

Norte, F. A.: Características del viento Zonda en la Región de Cuyo, $\mathrm{PhD}$ thesis, Buenos Aires University, Buenos Aires, Argentina, 1988.

Norte, F. A.: Understanding and Forecasting Zonda Wind (Andean Foehn) in Argentina: A Review, Atmospheric and Climate Sciences, 5, 163, 2015.

Owen, P. R.: Saltation of uniform grains in air, J. Fluid Mech., 20, 225-242, 1964.

Park, S., Gong, S., Zhao, T., Vet, R., Bouchet, V., Gong, W., Makar, P., Moran, M., Stroud, C., and Zhang, J.: Simulation of entrainment and transport of dust particles within North America in April 2001 ("Red Dust Episode"), J. Geophys. Res., 112, D20209, https://doi.org/10.1029/2007JD008443, 2007.

Prospero, J. M., Ginoux, P., Torres, O., Nicholson, S. E., and Gill, T. E.: Environmental characterization of global sources of atmospheric soil dust identified with the Nimbus 7 Total Ozone Mapping Spectrometer (TOMS) absorbing aerosol product, Rev. Geophys., 40, 1002, https://doi.org/10.1029/2000RG000095, 2002.

Reckziegel, F., Bustos, E., Mingari, L., Báez, W., Villarosa, G., Folch, A., Collini, E., Viramonte, J., Romero, J., and Osores, M. S.: Forecasting volcanic ash dispersal and coeval resuspension during the April-May 2015 Calbuco eruption, J. Volcanol. Geoth. Res., 321, 44-57, 2016.

Romero, J., Morgavi, D., Arzilli, F., Daga, R., Caselli, A., Reckziegel, F., Viramonte, J., Díaz-Alvarado, J., Polacci, M., Burton, M., and Perugini, D.: Eruption dynamics of the 2223 April 2015 Calbuco Volcano (Southern Chile): Analyses of tephra fall deposits, J. Volcanol. Geoth. Res., 317, 15-29, 2016.

Seggiaro, R., Hongn, F., Folguera, A., and Clavero, J.: Hoja Geológica 2769-II. Paso de San Francisco: Programa Nacional de Cartas Geológicas 1: 250.000, Boletín 294, SEGEMAR, Buenos Aires, Argentina, 2000.

Seluchi, M. E., Norte, F. A., Satyamurty, P., and Chou, S. C.: Analysis of three situations of the foehn effect over the Andes (zonda wind) using the Eta-CPTEC regional model, Weather Forecast., 18, 481-501, 2003.

Shao, Y.: A model for mineral dust emission, J. Geophys. Res., 106, 20239-20254, 2001.

Shao, Y.: Physics and modelling of wind erosion, Springer Science \& Business Media, 2nd Edn., 37, 456 pp., https://doi.org/10.1007/978-1-4020-8895-7, 2008.
Shao, Y. and Dong, C. H.: A review on East Asian dust storm climate, modelling and monitoring, Global Planet. Change, 52, 122, 2006.

Shao, Y. and Leslie, L. M.: Wind erosion prediction over the Australian continent, J. Geophys. Res., 102, 30091-30105, 1997.

Shao, Y. and Lu, H.: A simple expression for wind erosion threshold friction velocity, J. Geophys. Res., 105, 22437-22443, 2000.

Shao, Y., Raupach, M. R., and Findlater, P. A.: Effect of saltation bombardment on the entrainment of dust by wind, J. Geophys. Res., 98, 12719-12726, 1993.

Shao, Y., Raupach, M. R., and Leys, J. F.: A model for predicting aeolian sand drift and dust entrainment on scales from paddock to region, Aust. J. Soil Res., 34, 309, https://doi.org/10.1071/sr9960309, 1996.

Skamarock, W. C., Klemp, J. B., Dudhia, J., Gill, D. O., Barker, D. M., Duda, M. G., Huang, X.-Y., Wang, W., and Powers, J. G.: A description of the Advanced Research WRF Version 3, Tech. rep., National Center for Atmospheric Research, Boulder, Colorado, USA, NCAR Technical Note, NCAR/TN-475+STR, 2008.

Stull, R. B.: An Introduction to Boundary Layer Meteorology, Kluwer Academic Publishers, Dordrecht, 1988.

Tegen, I.: Modeling the mineral dust aerosol cycle in the climate system, Quaternary Sci. Rev., 22, 1821-1834, 2003.

Tegen, I. and Fung, I.: Modeling of mineral dust in the atmosphere: Sources, transport, and optical thickness, J. Geophys. Res., 99, 22897-22914, 1994.

Tegen, I. and Schulz, M.: Numerical Dust Model, in: Mineral Dust: A Key Player in the Earth System, edited by: Knippertz, P. and Stuut, J.-B. W., Springer Netherlands, 201-222, 2014

Ulke, A. G.: New turbulent parameterization for a dispersion model in the atmospheric boundary layer, Atmos. Environ., 34, 1029 1042, 2000.

Uno, I., Carmichael, G., Streets, D., Tang, Y., Yienger, J., Satake, S., Wang, Z., Woo, J.-H., Guttikunda, S., Uematsu, M., Matsumoto, K., Tanimoto, H., Yoshioka, K., and Iida, T.: Regional chemical weather forecasting system CFORS: Model descriptions and analysis of surface observations at Japanese island stations during the ACE-Asia experiment, J. Geophys. Res., 108, 8668, https://doi.org/10.1029/2002JD002845, 2003.

Uno, I., Wang, Z., Chiba, M., Chun, Y., Gong, S., Hara, Y., Jung, E., Lee, S.-S., Liu, M., Mikami, M., Music, S., Nickovic, S., Satake, S., Shao, Y., Song, Z., Sugimoto, N., Tanaka, T., and Westphal, D. L.: Dust model intercomparison (DMIP) study over Asia: Overview, J. Geophys. Res., 111, D12213, https://doi.org/10.1029/2005JD006575, 2006.

Viramonte, J. G., Arnosio, J., Euillades, P., Blanco, M., Ash, G., Heit, B., Poodts, M., Castro Godoy, S., Becchio, R., Groppelli, G., and Klotz, J.: Cerro Blanco volcanic complex: a collapsing caldera in the Southern Central Andes?, International Association of Volcanologists and Chemistry of the Earth's Interior General assembly, Pucón, Chile, 14-19 November 2004.

Viramonte, J. G., Arnosio, M., Becchio, R., Gropelli, G., Norini, G., Corazzatto, C., DiFillipo, M., Blanco, M., Eulillades, P., Poodts, M., Castro Godoy, S., Klotz, J., Asch, G., and Heit, B.: Cerro Blanco Volcanic Complex: the youngest caldera system in the Southern Central Andes. A multidisciplinary Earth Science Project, Terra Nostra 05/1: 19, 19th Colloquium on Latin Ameri- 
can Geosciences, Potsdam, Germany, 18-20 April 2005, 135 pp., 2005.

Viramonte, J. G., Arnosio, M., Becchio, R., de Silva, S., and Roberge, J.: Cerro Blanco Volcanic Complex, Argentina: A Late Pleistocene to Holocenerhyolitic arc-related caldera complex in the Central Andes, International Association of Volcanologists and Chemistry of the Earth's Interior General assembly, Reykjavík, Iceland, 18-24 August 2008.

Vogel, B., Vogel, H., Bäumer, D., Bangert, M., Lundgren, K., Rinke, R., and Stanelle, T.: The comprehensive model system COSMOART - Radiative impact of aerosol on the state of the atmosphere on the regional scale, Atmos. Chem. Phys., 9, 8661-8680, https://doi.org/10.5194/acp-9-8661-2009, 2009.
Westphal, D. L., Toon, O. B., and Carlson, T. N.: A two-dimensional numerical investigation of the dynamics and microphysics of Saharan dust storms, J. Geophys. Res., 92, 3027-3049, 1987.

Wilson, T. M., Stewart, C., Bickerton, H., Baxter, P., Outes, V., Villarosa, G., and Rovere, E.: Impacts of the June 2011 PuyehueCordón Caulle volcanic complex eruption on urban infrastructure, agriculture and public health, GNS Science Report 2012/20, 88 pp., 2013.

Xuan, J. and Robins, A.: The effects of turbulence and complex terrain on dust emissions and depositions from coal stockpiles, Atmos. Environ., 28, 1951-1960, 1994. 